Nuntius Antiquus, Belo Horizonte, v. 12, n. 1, p. 215-257, 2016

\title{
Helenê kinêmatographikê; or, Is this the face that launched a thousand films?
}

\section{Helenê kinêmatographikê; ou, É esta a face que lançou mil filmes?}

Martin M. Winkler

George Mason University

Fairfax, VA - USA

mwinkler@gmu.edu

\begin{abstract}
In ancient Greece and Rome, Helen of Troy was the most beautiful woman among mortals. Her beauty, an almost divine quality, made Helen immortal. Its praise was an integral part of Greek and Roman letters. The cinema has eagerly followed in the footsteps of classical and later authors and artists by retelling her story. Beautiful actresses have variously portrayed her as unhappy wife of Menelaus, romantic lover of Paris, and ruinous cause of the Trojan War. This paper pays homage to Helen's beauty by presenting, in word and image, her most notable screen incarnations from 1911 to 2013.
\end{abstract}

Keywords: Helen of Troy; film/cinema; romance; tragedy; actresses playing Helen.

Resumo: Na Grécia e Roma antigas, Helena de Troia era a mulher mais bela entre as mortais. Sua beleza, uma qualidade quase divina, tornou Helena imortal. Seu elogio era uma parte integrante das literaturas grega e romana. O cinema acompanhou avidamente as marcas deixadas por autores e artistas dos períodos clássico e posterior, recontando a história dela. Belas atrizes a representaram de diversas maneiras, como a infeliz esposa de Menelau, a amante romântica de Páris ou a funesta causa da 
guerra de Troia. Este artigo presta uma homenagem à beleza de Helena, apresentando, em palavras e imagens, suas encarnações mais notáveis na tela, de 1911 a 2013.

Palavras-chave: Helena de Troia; filme/cinema; romance; tragédia; atrizes encenando Helena.

Artigo recebido em 12 de junho de 2015 Aprovado para publicação em 8 de agosto de 2015

Aphrodite, Helen, and Cleopatra are probably the three women of classical myth and history who are most renowned for their beauty. The story of the Judgment of Paris closely associates the two mythical ladies with each other. Aphrodite wins the divine beauty contest when she promises Paris the most beautiful mortal woman: her bribe and his bride. Cherchez les femmes: female beauty is the direct cause of antiquity's biggest myth. Hinc illae lacrimae belli Troiani.

Praise of Helen's beauty was an integral part of Greek and Roman letters. This beauty received its ultimate tribute in a composition by the Greek rhetorician Isocrates, a disciple of the Sophist Gorgias. Isocrates' Tenth Oration is the Encomium to Helen, which responds to Gorgias' own Encomium to Helen, which in turn was a reply to Stesichorus' Palinode. ${ }^{1}$ Isocrates attributes to Helen the greatest beauty, which is the most divine quality and made Helen herself immortal. Even as a young girl and before reaching the full bloom of her beauty, Isocrates says, Helen already surpassed all other women. She even bewitched the great hero Theseus, himself a model of male handsomeness. ${ }^{2}$ Isocrates reports that sometimes Helen was credited with having been at Homer's side as he was composing his epics and

\footnotetext{
${ }^{1}$ On this, and on portrayals of Helen chiefly in American films, see Winkler (2009, rpt. 2012 p. 210-250, chapter titled "Helen of Troy: Marriage and Adultery According to Hollywood"). See further the brief overview by Rodrigues (2012). On Helen in ancient visual arts see LIMC 4 (1988, p. 498-572, s. vv. Helene and Elina); for the wider context (classical and later art) see Scherer (1964, especially p. 10-23, 28-39, and 115-123).

${ }^{2}$ Plutarch, Theseus 31; Hyginus, Fabulae 79; Apollodorus, Library, Epit. 1.23, are among the chief sources for this part of Theseus' and Helen's myths. Theseus was so deeply smitten with Helen that he kidnapped her. On the subject of classical beauty see now Konstan (2014).
} 
so made the Iliad and the Odyssey the surpassing works that they are. How then can we not honor Helen, Isocrates exclaims rhetorically. Philosophers and the educated are duty-bound to praise Helen in homage to her beauty. ${ }^{3}$ Beginning with the early twentieth century, the cinema has eagerly heeded Isocrates' call.

\section{Art, beauty, and a little sex}

INTERIOR. DAY. A studio projection room. A director who has just previewed his new film for his bosses enthusiastically explains its meaning and purpose:

You see? [...] It teaches a lesson, a moral lesson, it has social significance. I want this picture to be a commentary on modern conditions, stark realism, the problems that confront the average man.

The bosses have other things in mind. One of them immediately comes to the point: "But with a little sex." The director continues pontificating: "I want this picture to be a document. I want to hold a mirror up to life. I want this to be a picture of dignity, a true canvas of the suffering of humanity." Again he meets with the same objection: "But with a little sex in it." Resigned, he agrees: "With a little sex in it."

The opening scene of Preston Sturges's Sullivan's Travels (1941) cleverly, poignantly, and humorously points us to the quandary that the cinema has always found itself in: the quarrel of art with commerce. "I wanted to make $[\ldots]$ something that would realize the potentialities of film as the sociological and artistic medium that it is," the director will soon add. But since Sullivan's Travels is a comedy, the scene ends on the side not of social significance but of the cinema's eternal appeal: "With a little sex in it."

Films have always hyped the sex appeal of beautiful actresses and promoted female beauty whenever, wherever, and however possible.

\footnotetext{
${ }^{3}$ See Isocrates, Encomium to Helen 18, 38, 54-55, 60-61, 65-66, and 69 (Isocrates' encouragement to others to follow his example). Snell (1973) summarizes ancient views of Helen. See further Homeyer (1977). Blondell (2013) is a recent study with extensive references.
} 
A minor but still amusing example occurred in 1942 with a Sweater Girl Contest designed to attract audiences to a musical comedy that was also a murder mystery. The film was called - what else? - Sweater Girl. (No, it did not star Lana Turner.) Its trailer whetted prospective viewers' appetite by asking them about history's most outstanding women: "Venus de Milo, Helen of Troy, Cleopatra, Anne Boleyn, Lillian Russell, Madame DuBarry. Who are these ladies? They are the famous Sweater Girls of history." Classical scholars would, of course, rather call the first three of these ladies peplos girls. But only Beckmessers will grumble at this homage to classical curves and culture.

\section{Fade-in}

INTERIOR. DAY. A bedroom. We are observing a married couple in an intimate moment. The wife, unclothed, is lying on her stomach; her husband is playing with her blond hair. Over romantic strings surging on the soundtrack, she begins to ask him a series of questions. Does he find her feet, ankles, knees and thighs, her derrière, her breasts and nipples, her shoulders and arms, her face with its mouth, eyes, and nose, her ears beautiful? Each time he answers in the affirmative. Meanwhile the camera is gliding along her body in a kind of visual caress (FIG. 1). "Yes, everything," he replies at the end. "Then you love me completely," she concludes. He agrees: "Yes. I love you totally, tenderly, tragically." He does not yet know how right he is.

\footnotetext{
${ }^{4}$ My information and the quotations are taken from "Fabian Sweater Girl Contest Scores a Hit" (1942), with illustrations (of course).

${ }^{5}$ Images are screenshots taken from home-video editions of films, posters, publicity shots, lobby cards, or stills either from my own collection or in the public domain. Exceptions are Figs. 10 and 18, which are courtesy of the William Knight Zewadski Collection. All images appear in accordance with fair-use provisions.
} 


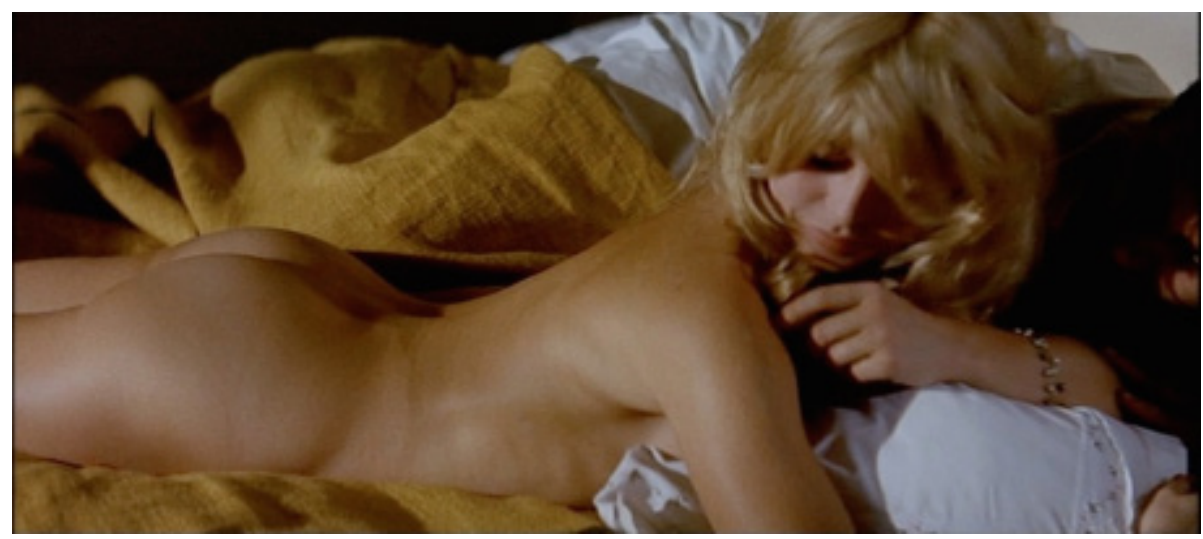

FIGURE 1: Le mépris. GODARD (1963)

No husband in his right mind would say anything different in reply to a wife's questions such as these, but we believe that this husband is sincere. So does his wife. Male viewers in particular will fully agree with the husband because his wife is being played by Brigitte Bardot. The scene here summarized occurs after the opening credits of Jean-Luc Godard's Contempt (Le mépris, 1963). It was added as an afterthought when the film's producers wanted to capitalize on the body of their star, who had already become a screen sensation and international sex symbol. The wife in Contempt is not Helen, but she will later leave her husband for another man. The film's plot, adapted from a novel by Alberto Moravia, involves the production of an epic film. It is to be called Odysseus and is based on Homer's Odyssey.

Bardot, pre-stardom, had had a supporting part in Robert Wise's Helen of Troy, in which she played Helen's handmaid Andraste. The name, as Adreste, occurs in a single line of the Odyssey (IV, 123). In retrospect, this piece of casting seems ironic, a missed opportunity. Might not B.B. have been the ultimate Helen of Troy? Her beauty and famous pout could have given Helen her screen apotheosis. Hélas pour nous, it was not to be. Still, enough beauties have embodied Helen on the screen to make a brief but appreciative survey worth our while.

The following pages and images provide a brief overview of the cinema's tributes to Helen's beauty. I limit myself to the most familiar examples and to a few others that deserve a rediscovery. I include, of course, what I consider to be her most ravishing incarnations. But there is 
an immediate problem with screen appearances of Helen, even if actresses famous for their beauty portray her. Beauty, as the saying goes, is in the eye of the beholder. Does not every film run the unavoidable risk of featuring an actress who may leave viewers cold or at least unimpressed? I don't think this one is beautiful enough for Helen, some viewers may think. Even worse, male viewers might conclude: This Helen is not my type, so I don't see why anybody should make such a fuss about her, much less get involved in a horrible war over her. Indeed, there is such a risk, as there is for screen portrayals of any of the sweater girls already mentioned. (There are, of course, yet others.) Operas and other stage plays can be in a comparable bind. No such problem applies to novels, of course, because their authors cannot show us what their beautiful heroines or seductresses actually look like. Christopher Marlowe's Doctor Faustus famously asked about Helen: "Was this the face that launched a thousand ships / And burnt the topless towers of Ilium?" ${ }^{\circ}$ His question has been endlessly quoted, usually with the first verb in the present tense. Nowadays, when real women play Helen, the question may be worth pondering more than at Marlowe's time, when a boy actor embodied Helen.

\section{Beauty parade: the main attractions}

Notwithstanding this drawback, let us now begin our stroll, in chronological order, through a highly selective gallery of cinematic beauties and appreciate the efforts of producers, directors, screenwriters, actresses, and the latters' make-up and costume designers to give us not only the faces but also the bodies that launched a thousand films. This number is rhetorical hyperbole, but it is intended as a tribute to Marlowe.

Classical and biblical antiquity provided the new medium of cinema with a vast treasury for its visual stories from its earliest time. It took the cinema about a decade after its birth in 1895 to become sophisticated enough for epics - or mini-epics, as we might call them in retrospect. (We might consider them modern epyllia.) But technical and aesthetic developments had reached astonishing heights by the mid-1910s. Our first

\footnotetext{
${ }^{6}$ This quotation from Scene 13 of Dr. Faustus (or The Tragicall History of the Life and Death of Doctor Faustus) is taken from Marlowe (2003, p. 390). The complicated textual history of the play, published in 1604 (the A text) and 1616 (the B text), need not concern us here.
} 
three films are representative of this stage. Three years after the first one, its co-director Giovanni Pastrone made history with his colossal superproduction Cabiria, which influenced the entire course of epic filmmaking.

\subsection{La caduta di Troia ("The fall of Troy", 1911)}

Giovanni Pastrone and Luigi Romano Borgnetto directed this half-hour silent epic, which must have looked spectacular at its time even though the Trojan War myth is much abbreviated. The film combines outdoor scenes with large and impressive sets. During the opportune absence of her husband Menelaus from Sparta, Paris begins wooing Helen in her sumptuous palace garden, which is real except for its painted backdrop (FIG. 2). Soon he will succeed with the help of Aphrodite, whose divine nature is indicated by a double exposure that makes her appear almost diaphanous (FIG. 3). Helen is played by Mme. Davesnes, now virtually unknown. As was the case with several famous actresses of that time, she is rather too voluminous to be regarded as a great beauty today.

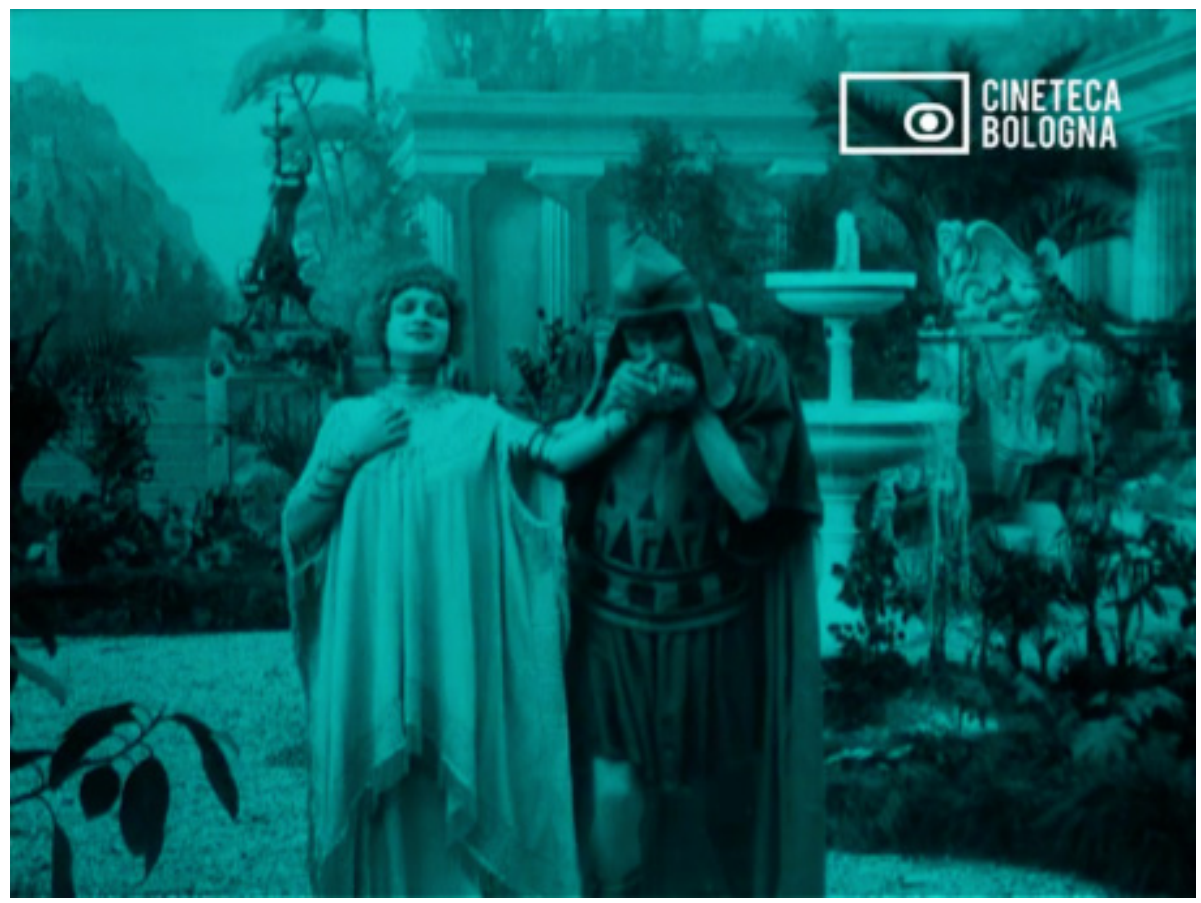

FIGURE 2: La caduta di Troia. PASTRONE; BORGNETTO (1911) 
222 Nuntius Antiquus, Belo Horizonte, v. 12, n. 1, p. 215-257, 2016

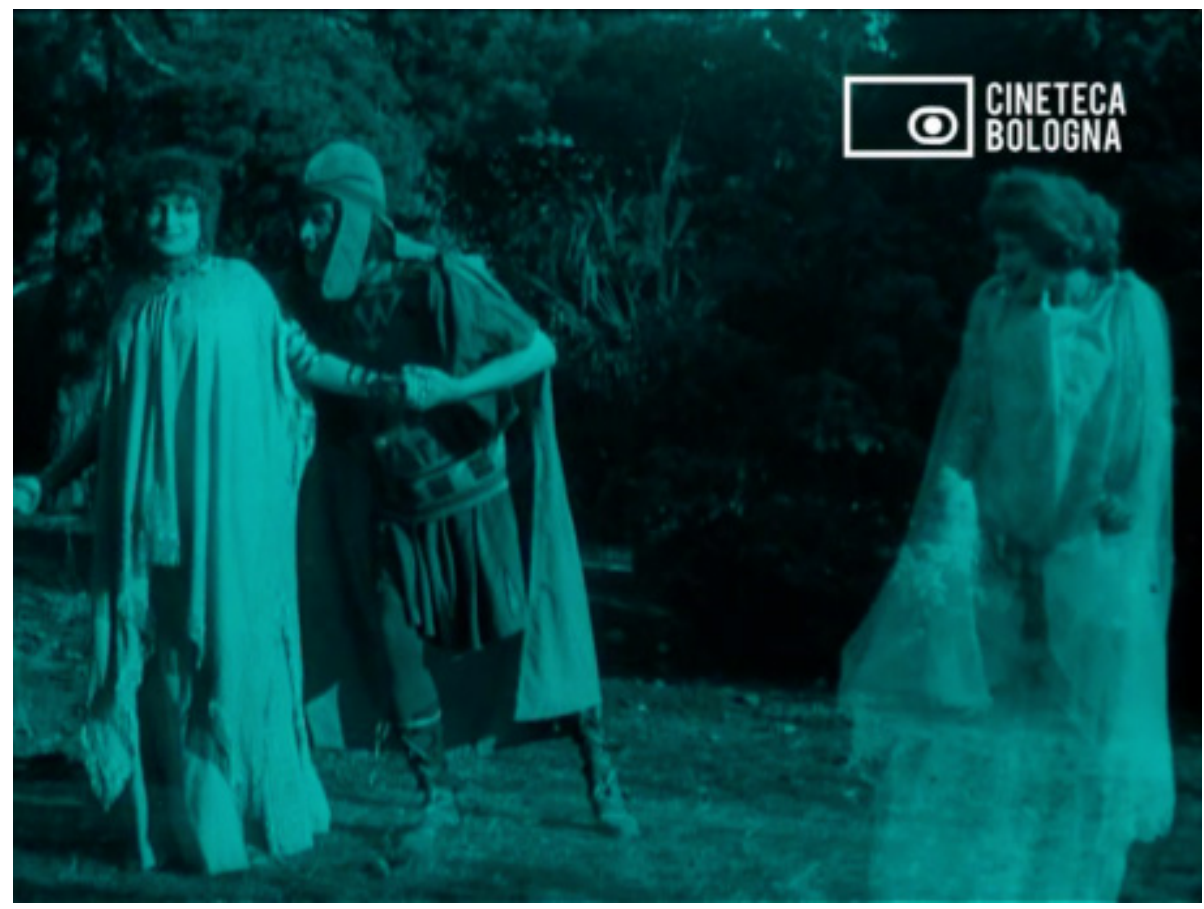

FIGURE 3: La caduta di Troia. PASTRONE; BORGNETTO (1911)

\subsection{Helena: Der Untergang Trojas ("Helen: The Fall of Troy", 1924)}

Now largely unknown and overshadowed in its own time by more prestigious UFA productions, this German epic with a total running time of almost four hours awaits rediscovery. Sometimes called simply Helena (U.S. title: Helen of Troy), it was directed by Manfred Noa on Bavarian locations and huge sets and starred Italian-born Edy Darclea as Helen. The film is a free rendition of Homer's Iliad, telling the myth of the Trojan War in two parts: Der Raub der Helena ("The Abduction of Helen") and Die Zerstörung Trojas ("The Destruction of Troy"). A French poster gives us a good idea of the film's visual splendor (FIG. 4). The story opens on the island of Cythera, sacred to Aphrodite. Helen has been chosen as queen of the festival and holds in her hands a dove, a symbol of the goddess and her power, which is not always as harmless as the cute little bird might mislead us into thinking (FIG. 5). Helen will shortly meet Achilles, who immediately becomes enamored of her. 
Nuntius Antiquus, Belo Horizonte, v. 12, n. 1, p. 215-257, 2016

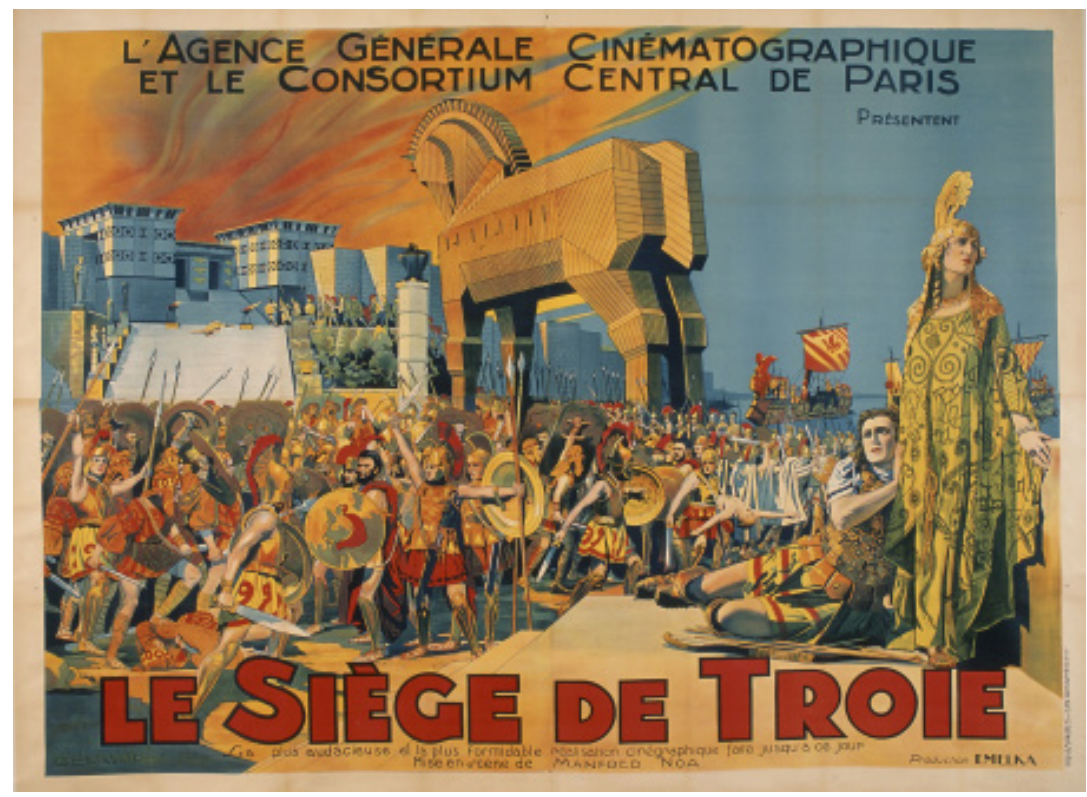

FIGURE 4: Helena: Der Untergang Trojas. NOA (1924)

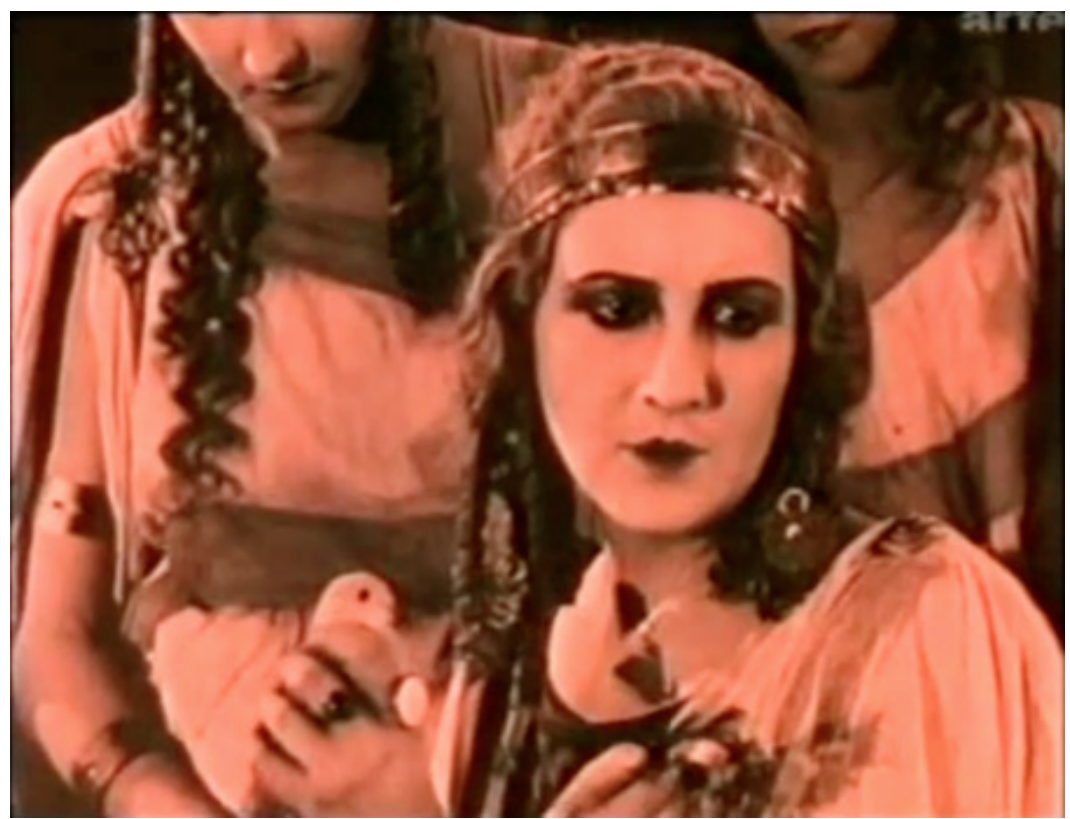

FIGURE 5: Helena: Der Untergang Trojas. NOA (1924) 
224 Nuntius Antiquus, Belo Horizonte, v. 12, n. 1, p. 215-257, 2016

\subsection{The Private Life of Helen of Troy (1927)}

John Erskine's 1925 novel by this title, set in Sparta after the Trojan War, began with this "Note" by the author:

After Troy, Helen reestablished herself in the home.

It will be seen that apart from her divine beauty and entire frankness she was a conventional woman.

Well, not quite, for this Helen is no cricket on the hearth but rather an emancipated (avant la lettre) and independent-minded wife. As the advertising copy for a 1942 reprint informed readers: "Mr. Erskine takes one of the most beautiful women of all time, and makes her breathe and live. [...] Mr. Erskine has adapted the story from Greek legend and fact [!] with brilliant wit and spirit, giving it the actual feeling of modern times and conditions." Dr. Erskine, Professor of English at Columbia University and the inspiration for the Great Books initiative, has indeed done just this. His paperback publishers, however, tended to add a little more sex with their covers. FIGS. 6 and 7 show examples; the latter is known by connoisseurs as "that naughty nipple cover." 8

\footnotetext{
${ }^{7}$ Quoted from the inside front flap of the dust cover for John Erskine, The Private Life of Helen of Troy (1942). The text below the cover image of this edition asks, rhetorically: "What kind of woman was the beautiful and unfaithful Greek wife whose face launched a thousand ships and destroyed a nation?"

${ }^{8}$ The editions in question are these: John Erskine, The Private Life of Helen of Troy (New York: Graphic Books, 1956 [Graphic Giant G-216]); John Erskine, The Private Life of Helen of Troy (New York: Popular Library, 1947; 2nd ed., 1948 [no. 147]).
} 
Nuntius Antiquus, Belo Horizonte, v. 12, n. 1, p. 215-257, 2016

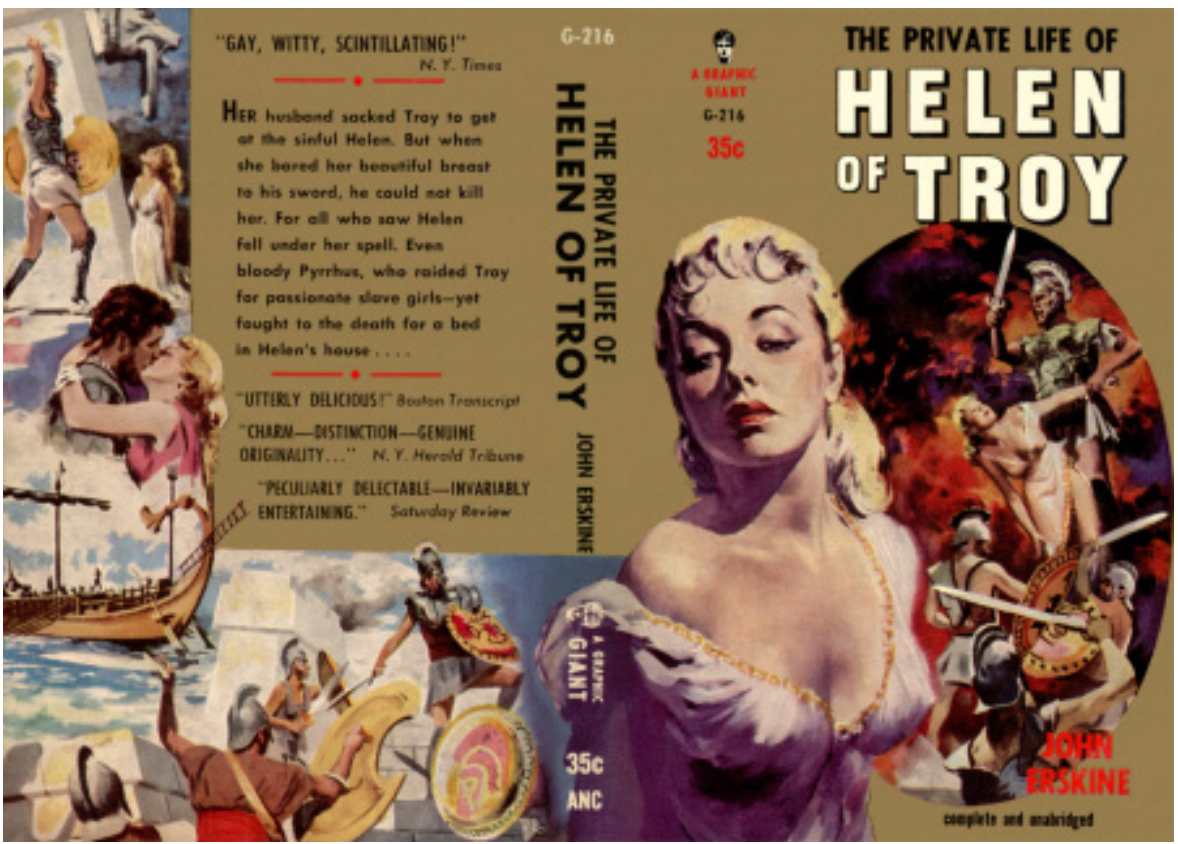

FIGURE 6: The private life of Helen of Troy. ERSKINE (ed. 1956) 
226 Nuntius Antiquus, Belo Horizonte, v. 12, n. 1, p. 215-257, 2016

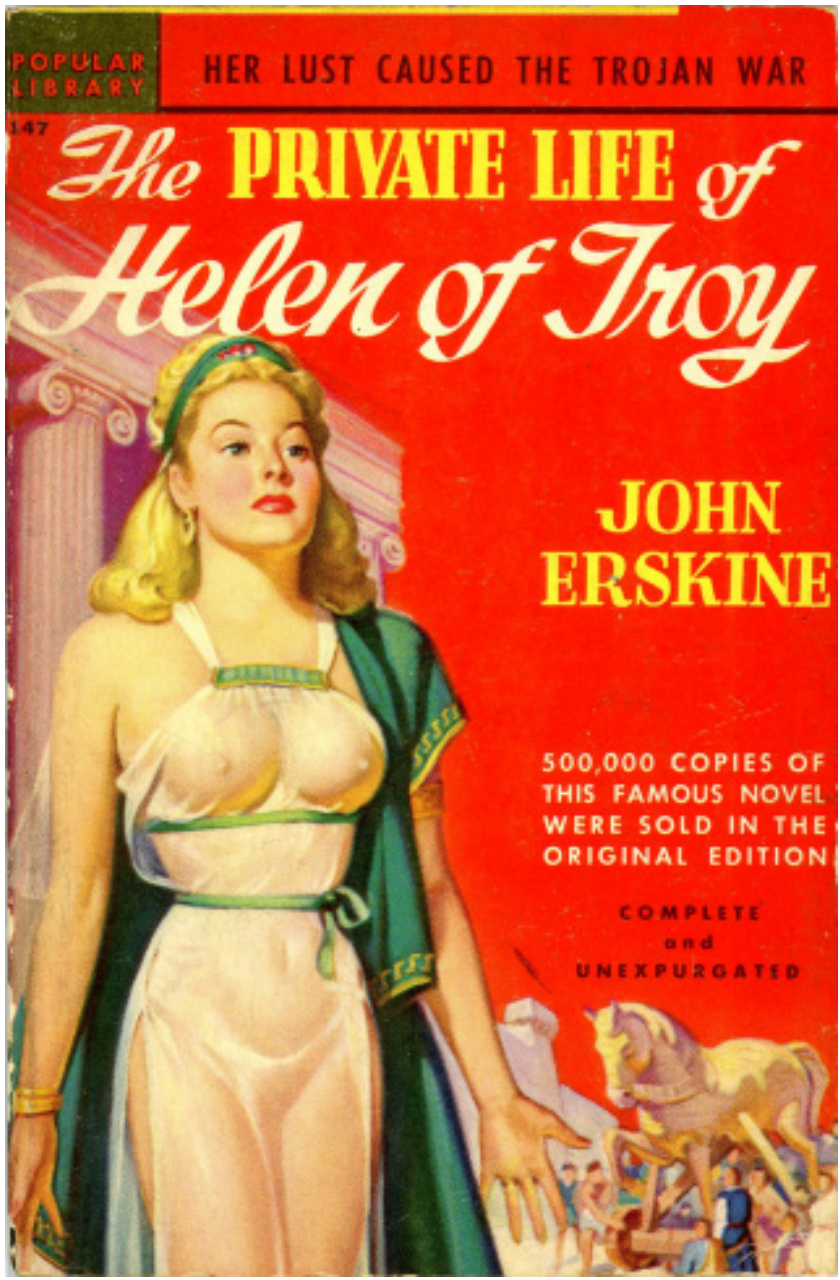

FIGURE 7: The private life of Helen of Troy. ERSKINE (ed. 1948)

Erskine's novel was combined with parts of Robert Sherwood's play The Road to Rome (!) for this film by expatriate Hungarian Alexander Korda, who was at this time in Hollywood. He himself directed; his wife Maria Corda was Helen. (The different spelling is intentional.) Perky starlet Alice White was Adraste. Impeccable Art Deco sets and costumes gave the film much of its visual appeal. A contemporary ad in Photoplay Magazine touted the film's virtues, although it made Helen 
simultaneously a blonde and a redhead (FIG. 8). Glamor shots of Corda show her in different moods, ranging from cutely romantic playgirl to regal fashion plate (FIGS. 9-10). ${ }^{9}$ But the arrival of sound doomed her career. Korda's lavish romance-comedy-epic survives today only in fragments. Korda would, however, have a lasting impact on British cinema a few years later, beginning with The Private Life of Henry VIII (1933).

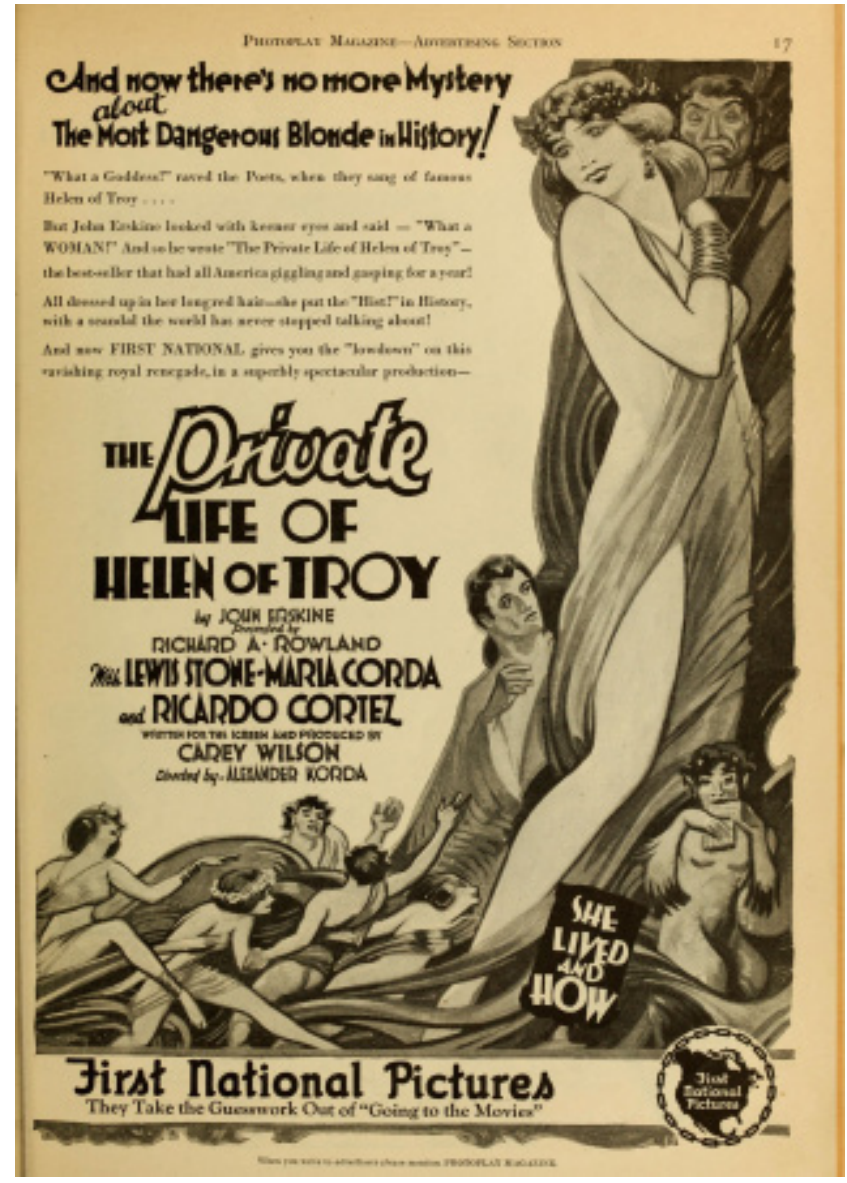

FIGURE 8: The private life of Helen of Troy. KORDA (1927)

${ }^{9}$ On this film see now Coelho (2013), with additional illustrations. 
228 Nuntius Antiquus, Belo Horizonte, v. 12, n. 1, p. 215-257, 2016

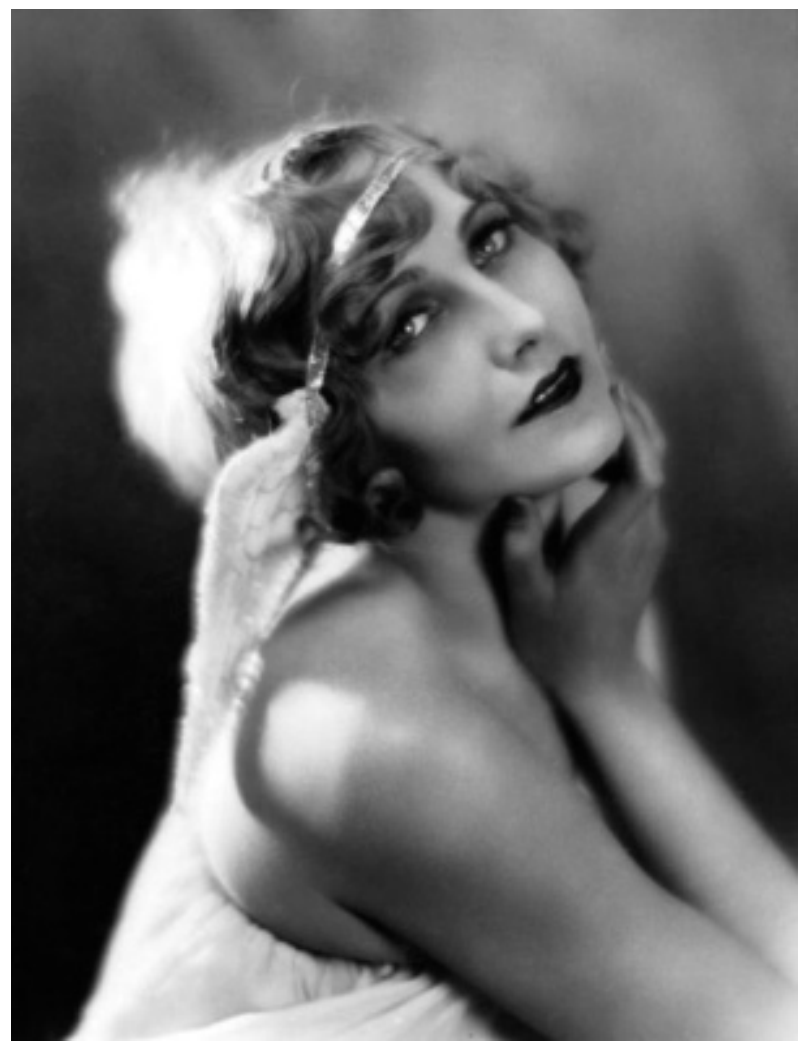

FIGURE 9: The private life of Helen of Troy. KORDA (1927) 


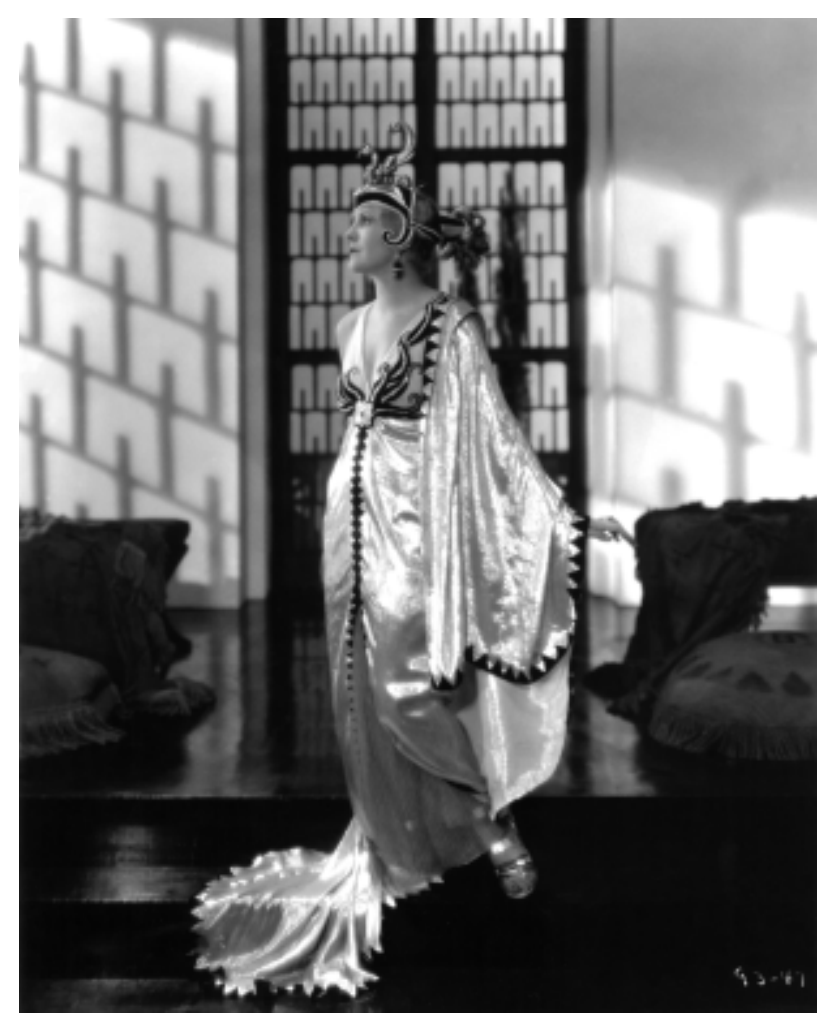

FIGURE 10: The private life of Helen of Troy. KORDA (1927)

Almost three decades were to elapse before another retelling of the Trojan War as costume epic appeared on international screens. In between, however, came an overlooked little gem.

\subsection{Sköna Helena (1951)}

Whether she is called, as here, "Beautiful Helen" or, as this film's English-language release was titled, "Helen of Troy," the lady is always attractive - never more so than when Eva Dahlbeck played her in this free Swedish adaptation of La belle Hélène, the popular opera buffa with music by Jacques Offenbach. (FIG. 11 shows a Swedish poster.) Gustav Edgren's film was not received too well by critics, partly because of its contemporary political overtones, but its titular lady makes it worth 
a look. Eva Dahlbeck would soon make her mark in film history with several romantic comedies or comedy-dramas written and directed by Ingmar Bergman: Waiting Women (1952), A Lesson in Love (1954), All These Women (1964), and the classic Smiles of a Summer Night (1955).

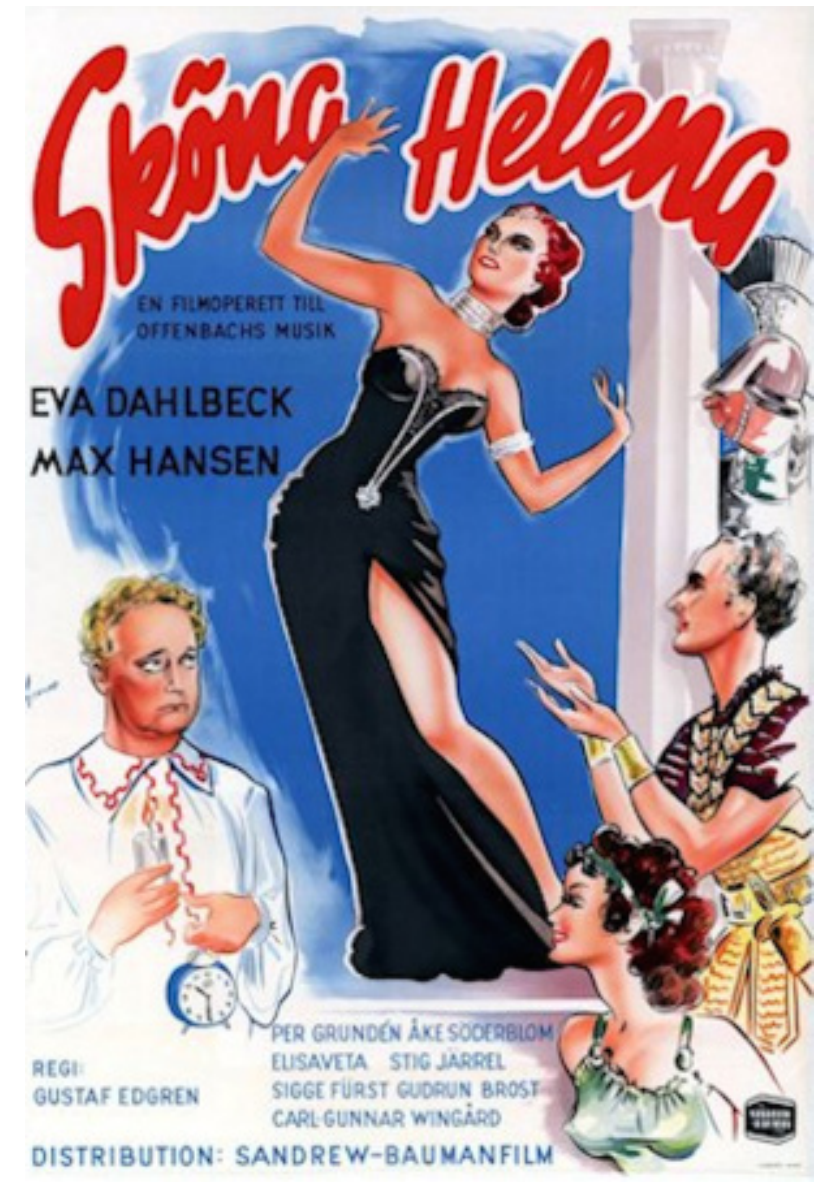

FIGURE 11: Sköna Helena. EDGREN (1951)

Offenbach's Helen even traveled to the wild American West in George Cukor's not-funny-enough comedy Heller in Pink Tights (1960), based on Louis L'Amour's 1955 novel Heller with a Gun. Sophia Loren plays an actress in a run-down traveling theater troupe, which is putting on La belle Hélène but runs into trouble with the puritan mayor 
of Cheyenne. What is this - a story about adultery? Not in his town! At least the film gives viewers the rare opportunity to watch a blond Sophia. In this poster she shows off her assets to good effect, even if she is not wearing the titular garments (FIG. 12).

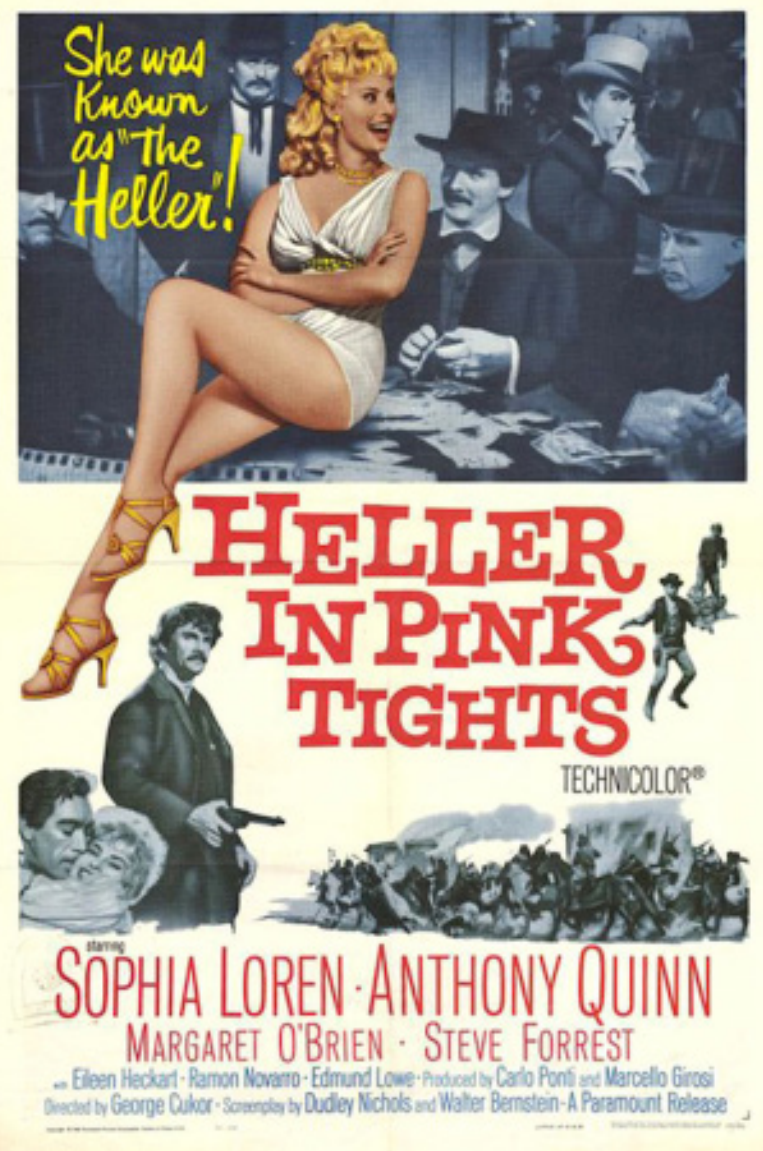

FIGURE 12: Heller in Pink Tights. CUKOR (1960)

With the introduction in the early 1950s of extreme widescreen cinematography, enhanced by color and stereophonic sound, film epics entered their most glorious phase, which lasted for a little over a decade. Ancient subjects - Greek myth, Roman history, tales from the Bible-almost dominated European and American screens. The Trojan War was back, too. 


\subsection{Helen of Troy (1956)}

With Ulysses (Ulisse, 1954) starring Kirk Douglas, Mario Camerini was the first director to turn to Homeric myth in the sound, color, and widescreen era. His Italian-American coproduction was soon followed by another one, Robert Wise's lushly romantic epic about Helen. ${ }^{10}$ (FIG. 13 shows a German poster.) Helen of Troy had a starstudded international cast and an appealing, if archaeologically fanciful, recreation of Minoan Knossos for the city of Troy. Its intelligent script made free with Homer and myth but presented a coherent retelling of the Trojan War. Its center is, of course, Helen, played by a young Rossana Podestà in a blond wig (FIG. 14). She had been a brunette Nausicaa in Camerini's film and had made a strong impression in Valerio Zurlini's The Girls of San Frediano (Le ragazze di San Frediano, 1955). As already mentioned, Helen's handmaid Adraste was Brigitte Bardot, who here is a brunette. Frenchman Jacques Sernas, billed as "Jack" in American ads, was Paris. The parallel scenes in which Podestà finds a handsome stranger on the shore, first as Nausicaa and then as Helen, are textbook cases of cinematic intertextuality, as academics call this sort of thing. Podestà acted in several other epic films with ancient or biblical settings but never had the career as a serious actress that she deserved. Peccato.

${ }^{10}$ Glücklich (2000, p. 97-108, especially p. 105-108) explains the film's romanticism as deriving from Ovid's Heroides 17 (a fictive letter from Helen to Paris). 


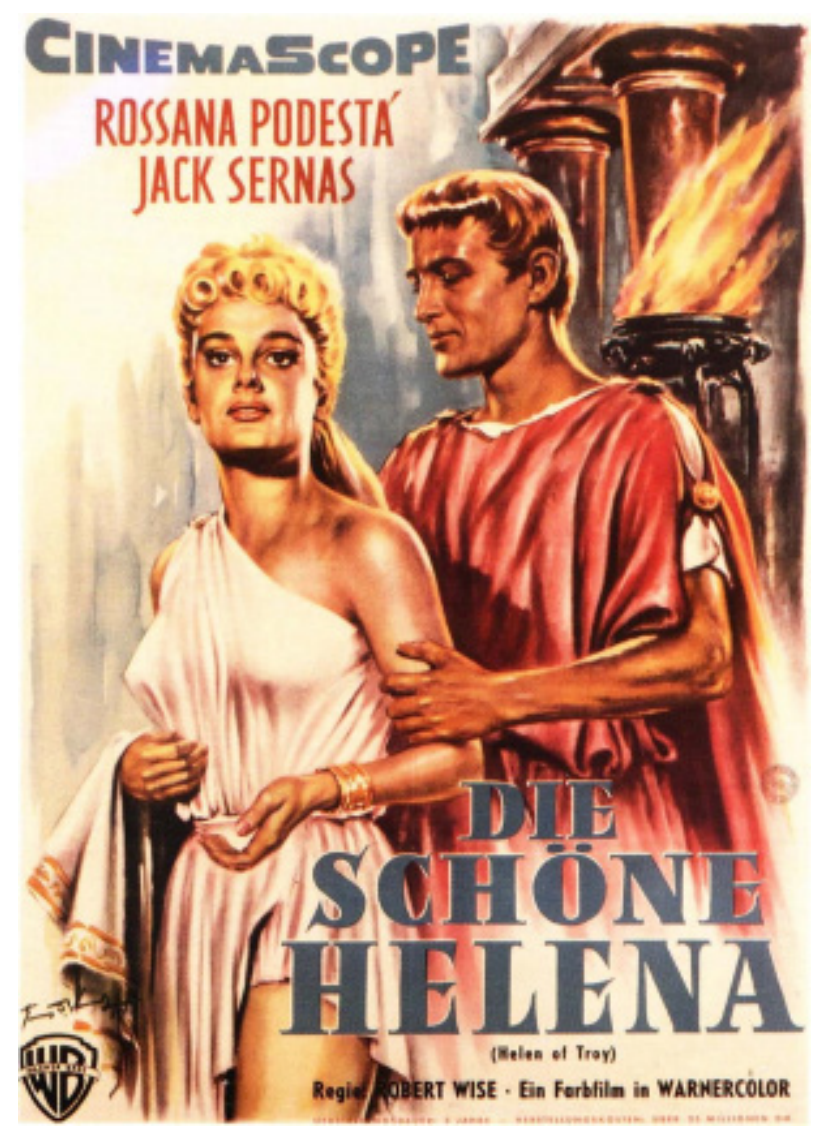

FIGURE 13: Helen of Troy. WISE (1957) 


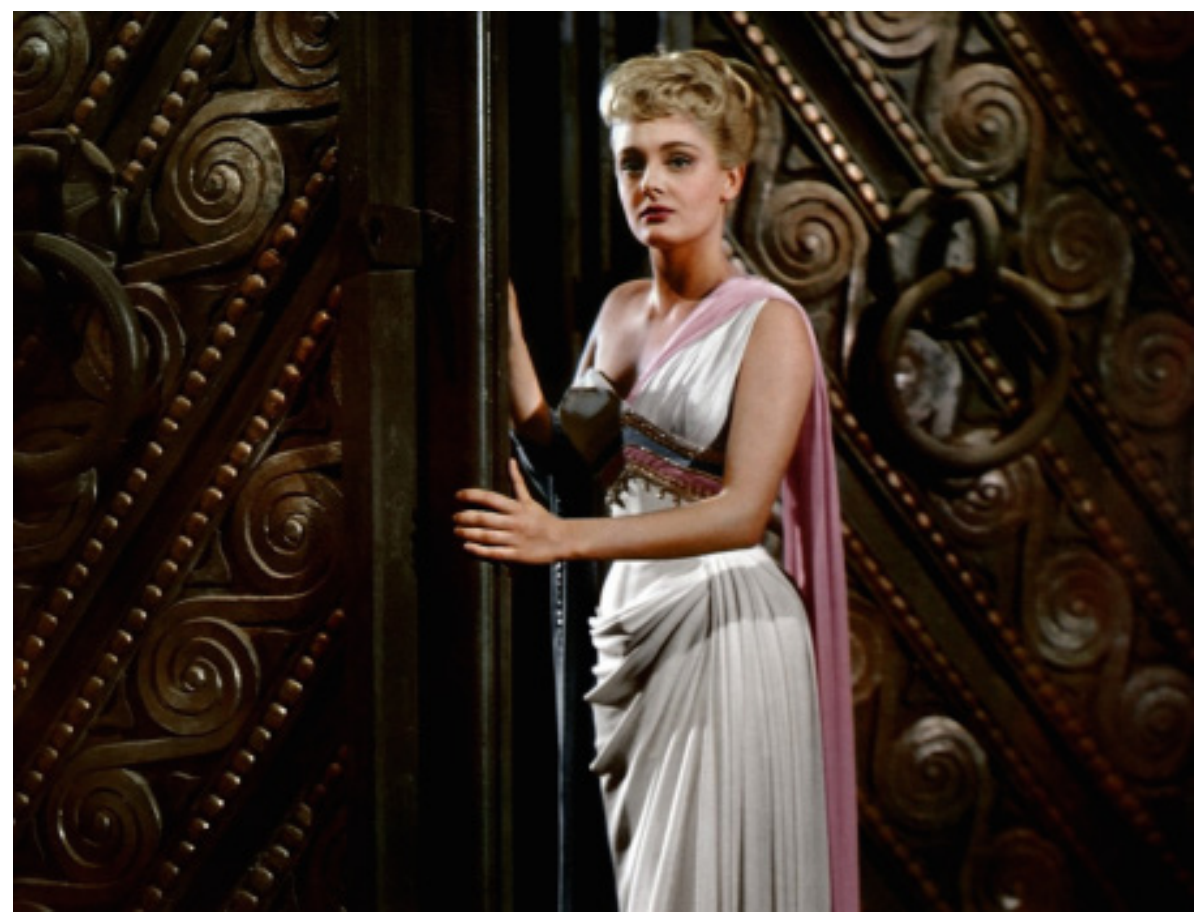

FIGURE 14: Helen of Troy. WISE (1957)

\subsection{La guerra di Troia (The Wooden Horse of Troy, The Trojan Horse; 1961)}

Giorgio Ferroni's underrated spectacle is yet another free reimagining. This time viewers are meant to be on the side of the Trojans. After Hector's death it is Aeneas, played by American body-builder Steve Reeves, who is the Trojans' greatest hero (FIG. 15). Paris is a cowardly villain scheming for power. By this time, Helen has nothing but contempt for him. She would much rather seduce Aeneas, who, however, is a faithful husband to Creusa and, as Troy's last hope, a responsible public figure. A very blond Hedy (elsewhere Edy) Vessel in colorful costumes makes for a great-looking Helen who can also act the aloof sexpot (FIG. 16). This Helen remains supremely unconcerned when Menelaus revenges himself on Paris by first demeaning him in his masculinity and then stabbing him before her very eyes. In 1963, Hedy Vessel was one of the many (and better-known) actresses in Federico Fellini's 81/2. 


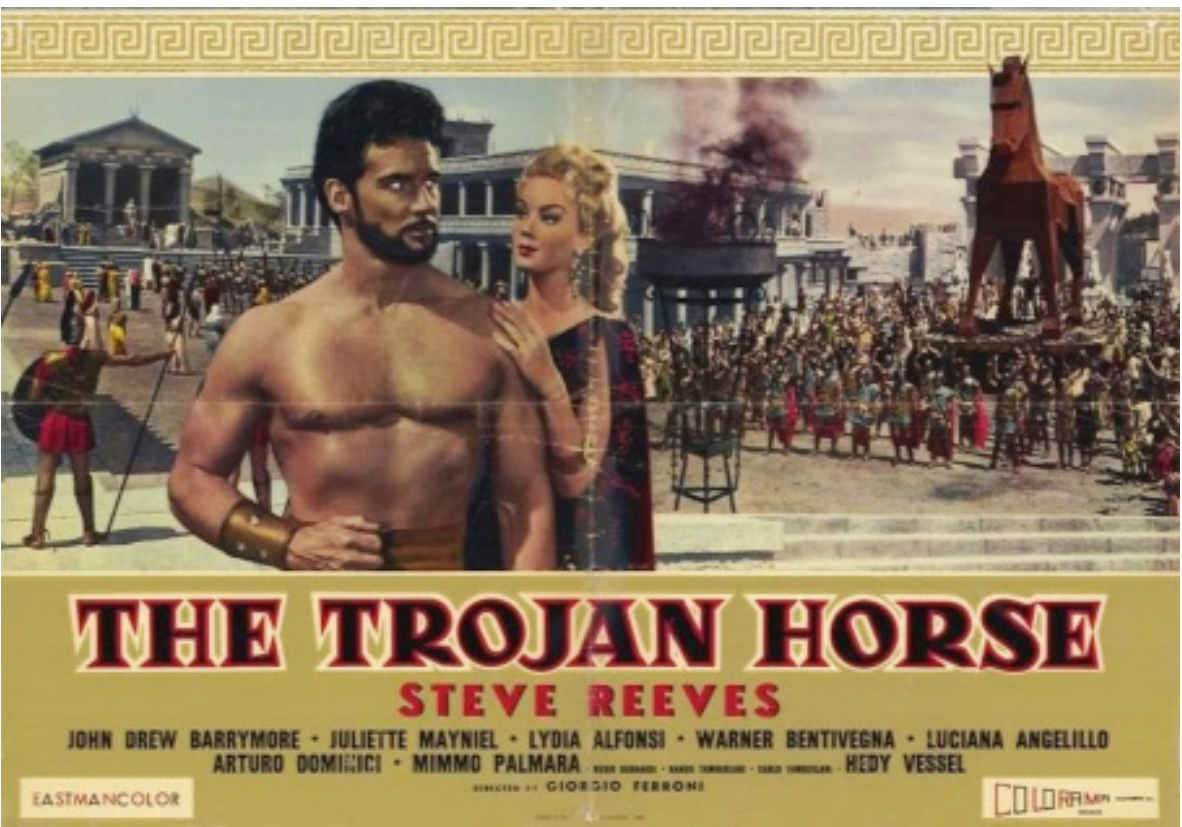

FIGURE 15: La guerra di Troia. FERRONI (1961) 


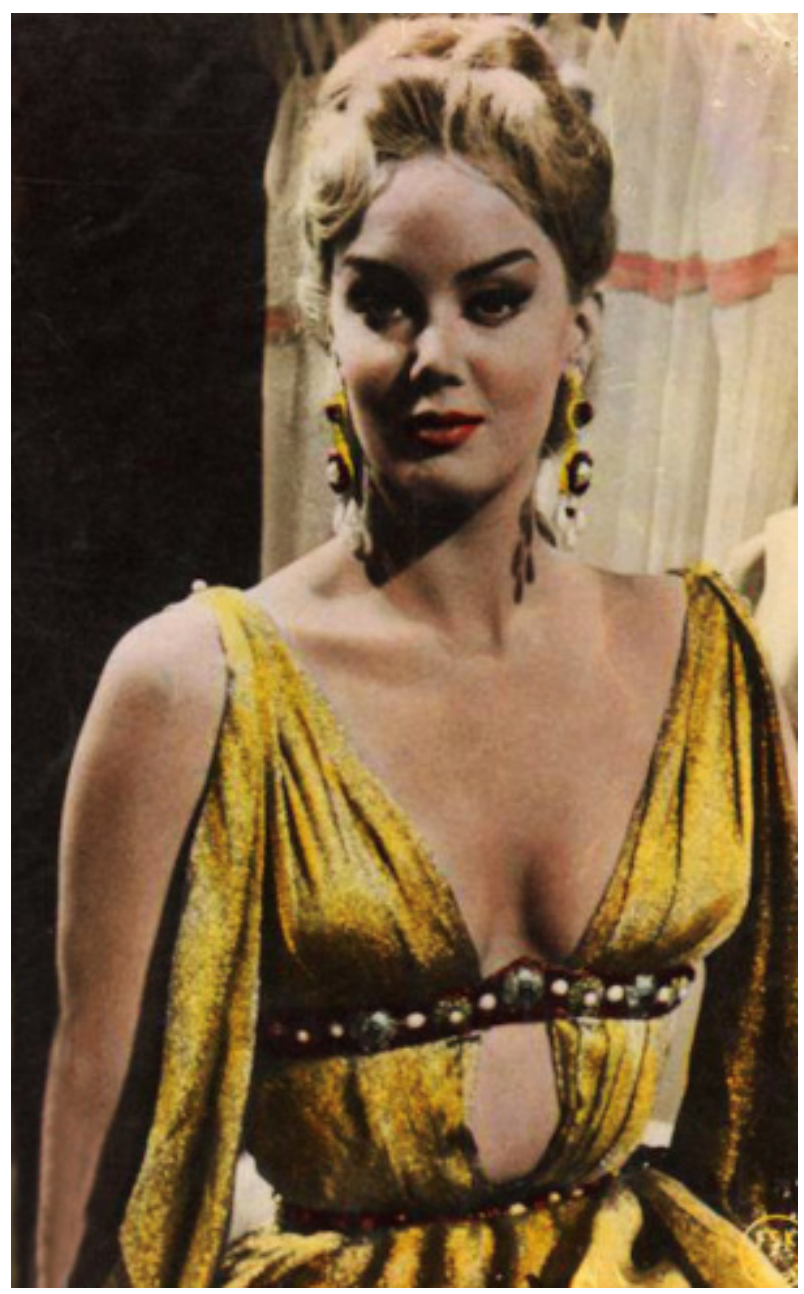

FIGURE 16: La guerra di Troia. FERRONI (1961)

\subsection{Il leone di Tebe (The Lion of Thebes, 1964)}

Giorgio Ferroni revisited the Trojan War, or rather its aftermath, with this somewhat inferior film. Greek myth and literature knew of two major versions concerning Helen's whereabouts during the war. She was either in Troy, as in Homer's and most later accounts, including Euripides' The Trojan Women, or in Egypt, as in Euripides' play Helen, with only a phantom of her in Troy. Ferroni here follows the Helen-in-Egypt topic, 
of course not faithfully. Ravishing French redhead Yvonne Furneaux is Helen. (FIG. 17 is a studio publicity shot unrelated to this film.) Helen has an invented muscleman for her protector and bodyguard. After the fall of Troy she is stranded in Egypt, where the titular city is located. Pharaoh Ramses, the target of a court intrigue, offers Helen hospitality and promptly falls for her charms, thus rousing the wrath of his bride, played by sexy Rosalba Neri (FIG. 18). When Ramses is assassinated, Helen is blamed. Although there is no tragic ending, there is no really happy ending, either. This rather melancholic Helen regrets her beauty, which has caused so much suffering. Furneaux frequently starred in commercial films like Ferroni's but also worked for such directors as Michelangelo Antonioni (Le amiche, 1955), Federico Fellini (La dolce vita, 1960), and Roman Polanski (Repulsion, 1965).

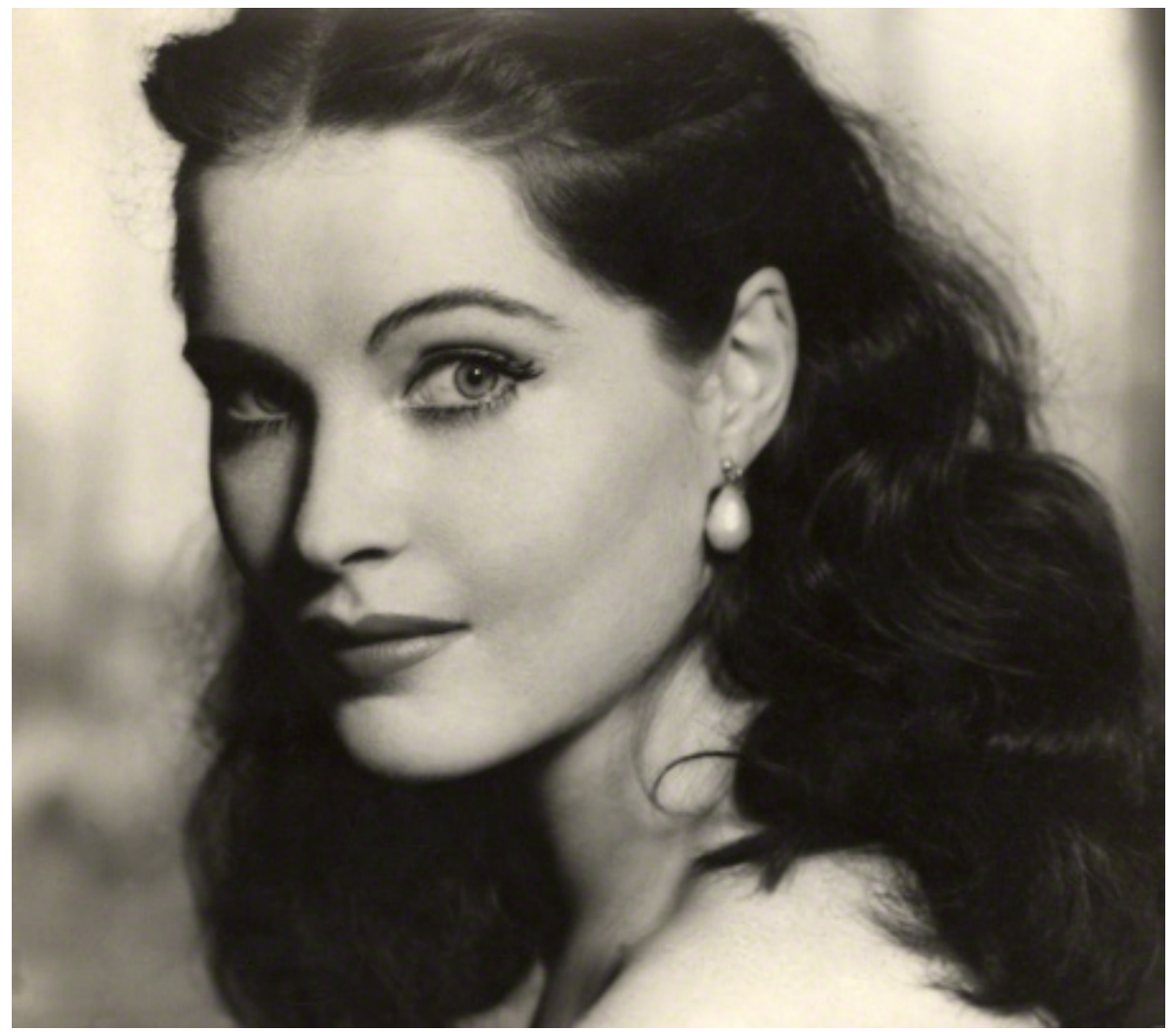

FIGURE 17: Yvonne Furneaux 


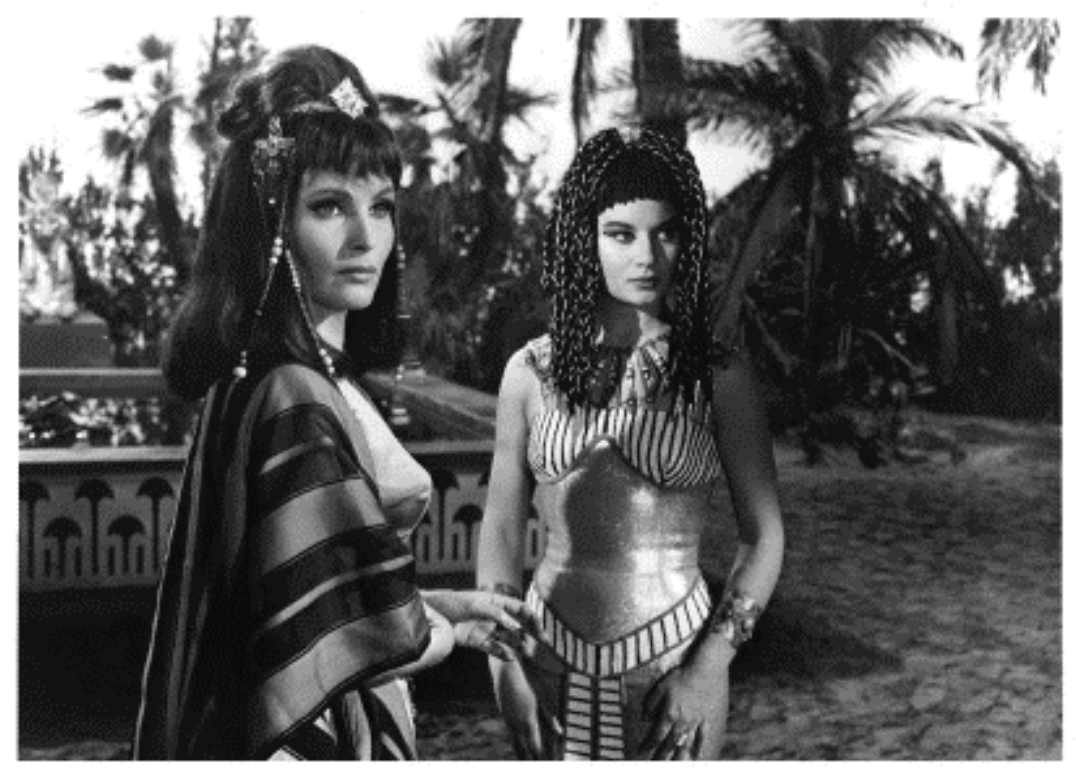

FIGURE 18: Il leone di Tebe. FERRONI (1964)

In the wake of the decline of gargantuan spectacles, smaller-scale art films and television productions became prominent. Often the latter were multi-part mini-series. The three films listed next are above-average examples of this development.

\subsection{Doctor Faustus (1967)}

This adaptation of Christopher Marlowe's play as a full-fledged costume drama was a dual labor of love for Richard Burton. As an actor, Burton preferred the theater to the cinema. But the cinema made possible his greatest love affair (and marriage) when he and Elizabeth Taylor madly and scandalously fell for each other during the production of Joseph L. Mankiewicz's Cleopatra, released in 1963. Co-directing Doctor Faustus with Oxford English professor Nevil Coghill, Burton, playing the title role, naturally cast Taylor as his Helen. (FIG. 19 is an Italian poster for the film.) The brief encounter between Faustus and a raven-haired "Helen of Greece," who does not speak a single line, is 
charged with palpable eroticism. When Mephistopheles conjures up "the admirablest lady that ever lived," an eerie but alluring and wholly supernatural musical theme with a prominent soprano vocalise announces "that peerless dame of Greece," who appears in silhouette. Close-ups of Faustus-Burton and Helen-Taylor, hers slightly larger than his, reveal the "queen, whose heavenly beauty passeth all compare." Faustus then approaches to embrace her, but her phantom vanishes. Clearly smitten, Faustus asks Mephistopheles to call her back. When she returns, with the same vocalise on the soundtrack, Faustus manages to caress her face as she smiles at him mysteriously in extreme close-up. He then delivers the famous line about the thousand ships and continues: "Come, Helen, make me immortal with a kiss." While they exchange a lingering kiss, the vocalise yields to romantic strings. A second kiss ("give me my soul again") while she is sitting on his lap is even more passionate. "Heaven is in these lips, and all is dross that is not Helena," Faustus declares - or is it Burton? Male viewers are likely to concur. The two kiss again. "None but thou shalt be my paramour," Faustus says as, with another kiss, their faces sink below the frame for an erotic encounter. Close attention to the words spoken as quoted here reveals that minuscule changes from Marlowe's wordings appear to have been introduced for modern viewers' easier comprehension. The darkness that has surrounded the lovers in both of Helen's scenes only enhances their intimacy. Taylor appears for no more than about five minutes but leaves a lasting impression. She is the only great actress ever to have played the two most famous human beauties of antiquity on our screens. 


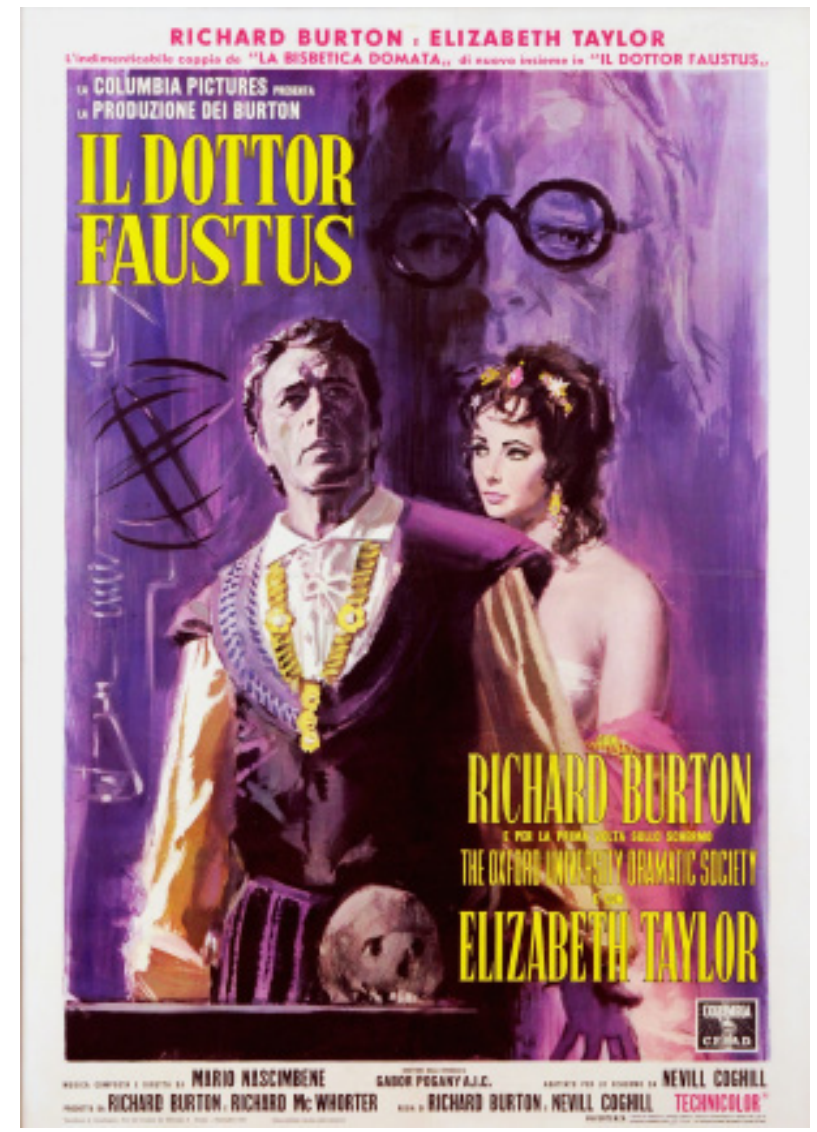

FIGURE 19: Doctor Faustus. BURTON; COGHILL (1967)

\subsection{Odissea ("The Odyssey", 1968)}

This six-hour film, produced by Dino de Laurentiis for Italian and European public television, is another labor of love and, astonishingly, an almost wholly successful adaptation of Homer's epic. It was chiefly directed by Franco Rossi, with a helping hand from horror and giallo master Mario Bava for the Polyphemus episode. A remarkable cast includes Greek actress Irene Papas as Penelope and Italian Scilla Gabel - the stage name of Gianfranca Gabellini - as Helen. Searching for information about his long-absent father, Odysseus' son Telemachus 
arrives in Sparta and, un-Homerically, is met by Helen. She takes him to Menelaus, who is still grieving for the friends and comrades he lost in the Trojan War, especially Odysseus. As in Homer, Helen soothes Menelaus and his guest by administering a supernatural drug; she then recounts to Telemachus her encounter with Odysseus in Troy, which we watch in a flashback. Unlike in Homer, this Helen is more important for the story and more in charge of her home than Menelaus. The mood Rossi creates for this episode is somber and dark; the film's narrator even characterizes Helen as la donna funesta when he introduces her to us. But the most powerful effect of the scene in Sparta and of the flashback to Troy derives from Gabel's unusual appearance. Except in the flashback her black hair is tightly pulled back into a large bun; the pronounced black make-up around her eyes makes her look almost Egyptian. All this, together with her regal bearing, creates an extremely mysterious woman (FIGS. 2021). Here we may well encounter the most eerily beautiful Helen of all.

In 1959 Scilla Gabel had doubled Sophia Loren in Boy on a Dolphin, a contemporary fiction about the discovery of an ancient Greek bronze sculpture. Gabel later appeared in several Greco-Roman costume dramas and, more memorably, in Giorgio Ferroni's gothic shocker Mill of the Stone Women (Il mulino delle donne di pietra, 1960). But Helen is her screen apotheosis. She and the entire film deserve a higher reputation and far greater appreciation than they have so far found. ${ }^{11}$

${ }^{11}$ Brief assessments are in Winkler (2010 and 2013). 


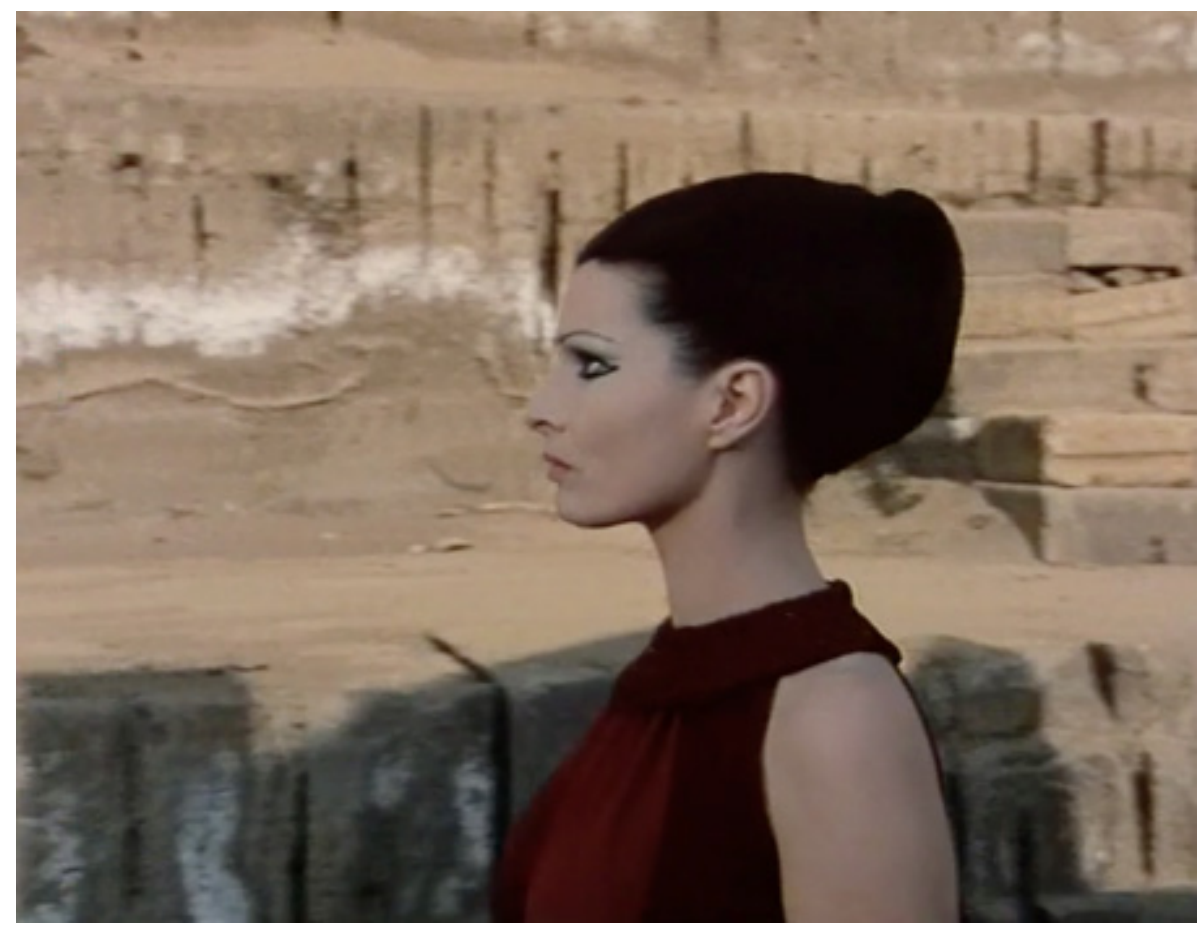

FIGURE 20: Odissea. ROSSI (1968) 


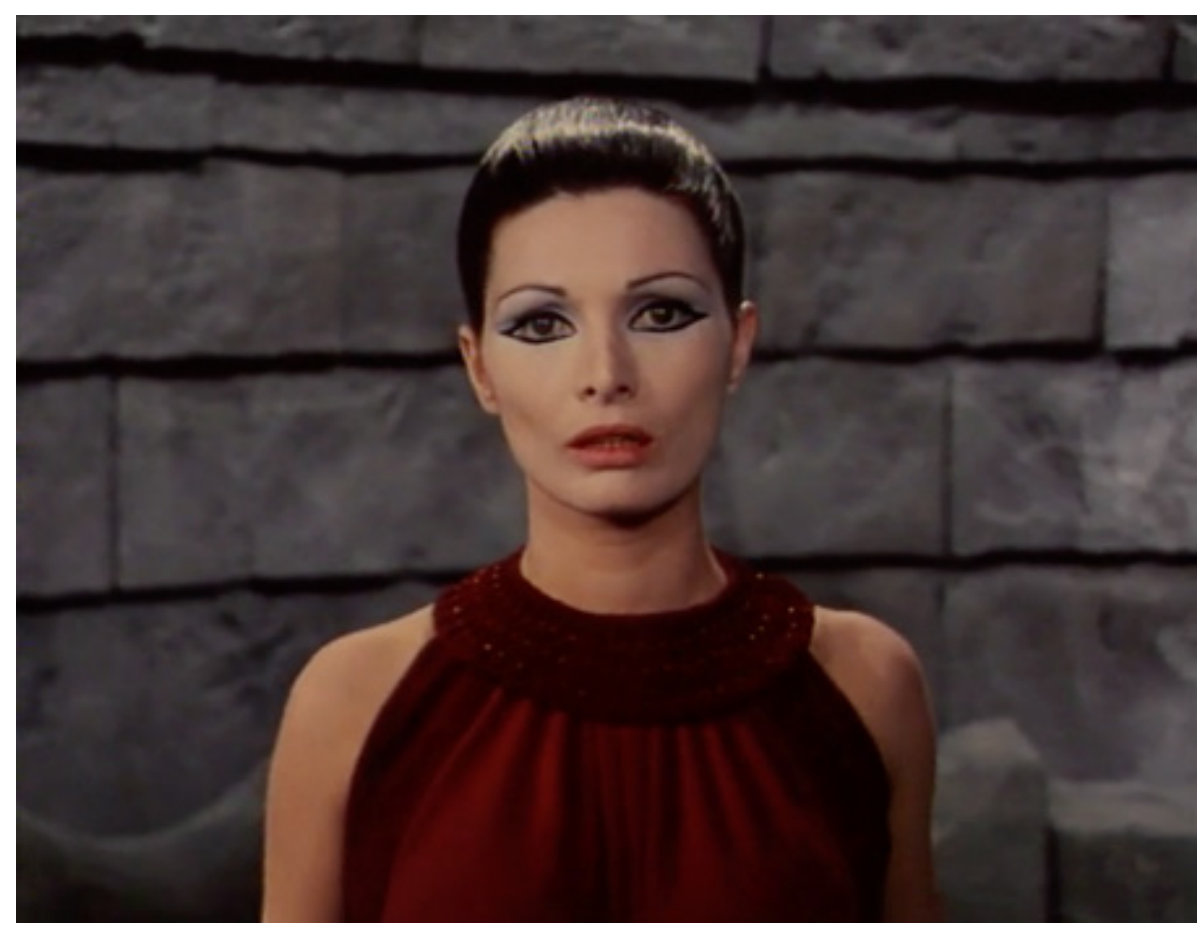

FIGURE 21: Odissea. ROSSI (1968)

\subsection{The Trojan Women (1971)}

Michael Cacoyannis wrote and directed three films of Euripidean drama, which all featured Irene Papas in major parts. She played the title character in Electra (1961) and Electra's mother Clytemnestra in Iphigenia (1977); in between came her Helen in The Trojan Women. This film is remarkable for its all-star female cast, which includes Katharine Hepburn, Vanessa Redgrave, and Geneviève Bujold.

The chorus of Aeschylus' Agamemnon characterizes Helen as a cute and playful lion cub that, once grown, causes a bloodbath among those who reared it in their home. ${ }^{12}$ Cacoyannis, too, resorts to animal imagery when he introduces his Helen to viewers. Held captive by the victorious Greeks after the fall of Troy, Helen looks out from behind

${ }^{12}$ Aeschylus, Agamemnon 717-736. 
the wooden planks of a dark shed. We only see her brooding eyes in an extreme close-up (FIG. 22). Cacoyannis has not yet informed us of this woman's identity, but it does not take us long to realize who she is and why she is a prisoner. We also find out that she is completely naked: defiantly and in full view of the outraged Trojan women, she uses a bowl of precious water for a quick bath. She is preparing herself for her first encounter with Menelaus after ten years. Later, dressed in a magnificent robe that keeps her back uncovered, she succeeds in wrapping Menelaus around her little finger. He was intent on killing her here and now, as Trojan queen Hecuba has urged him to do, but he changes his mind and takes her back home with him (FIG. 23).

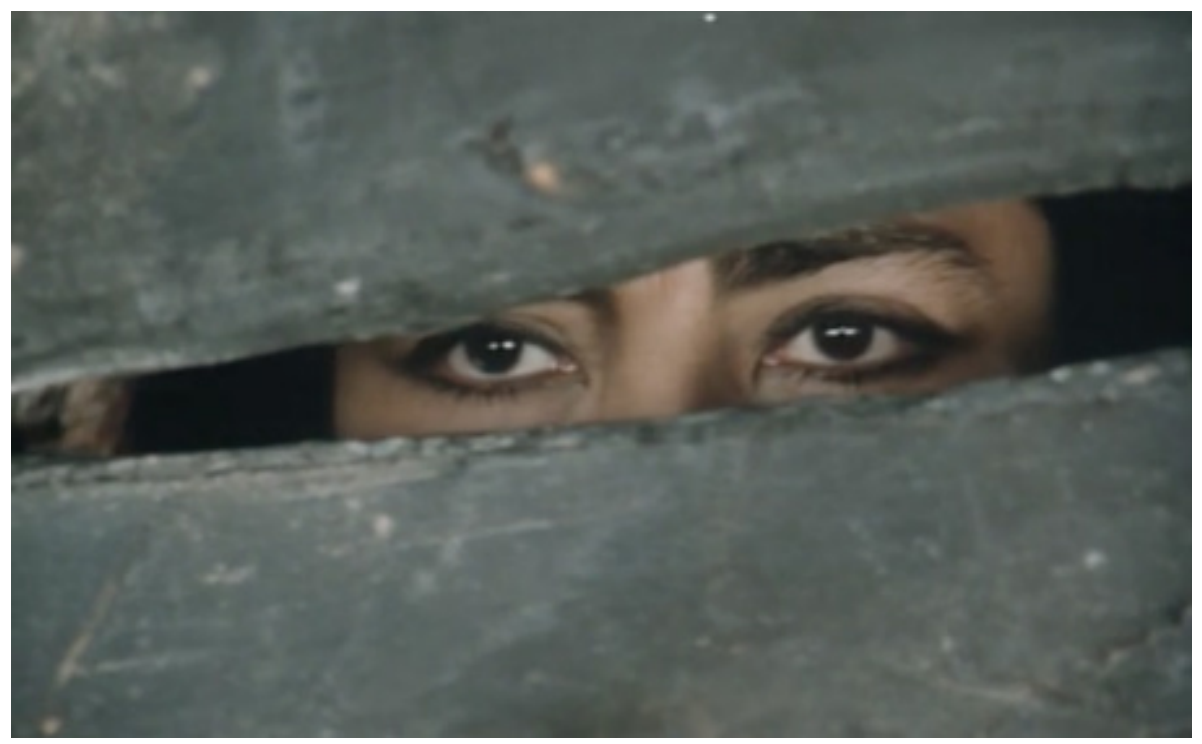

FIGURE 22: The Trojan Women. CACOYANNIS (1971)

Papas projects a mature sexuality. Her smoldering eroticism and the manner of her delivery of Euripides' lines (in English translation) make Helen's rhetorical victory over Menelaus and Hecuba entirely convincing to modern audiences. This Helen is fully conscious of her power over men and rejoices, not without arrogance, in surpassing all other women in her irresistible allure. Viewers understand why this ruinous but magnificent female animal has made so many men lose their heads and lives. The dress, of course, helps. Helen makes sure that 
its effect is not lost on Menelaus, and Cacoyannis at one point has his camera glide up Helen's bare back in extreme close-up. The dress is anachronistic but functions as the equivalent of something that Helen did with her clothing as reported in ancient sources but that Cacoyannis could never have put on the screen: when Menelaus finds her in Troy and is about to kill her, she bares her chest to accept his sword thrust. He throws his weapon away.

Papas had played the title part in Giorgos Tsavellas's Antigone (1961) and had been a memorable Penelope in Franco Rossi's Odissea. Eventually she was Odysseus' mother in Andrey Konchalovsky's American television film The Odyssey (1997). But her two greatest achievements in films of Greek myth were for Cacoyannis: a magnificent Helen and an unforgettable Clytemnestra.

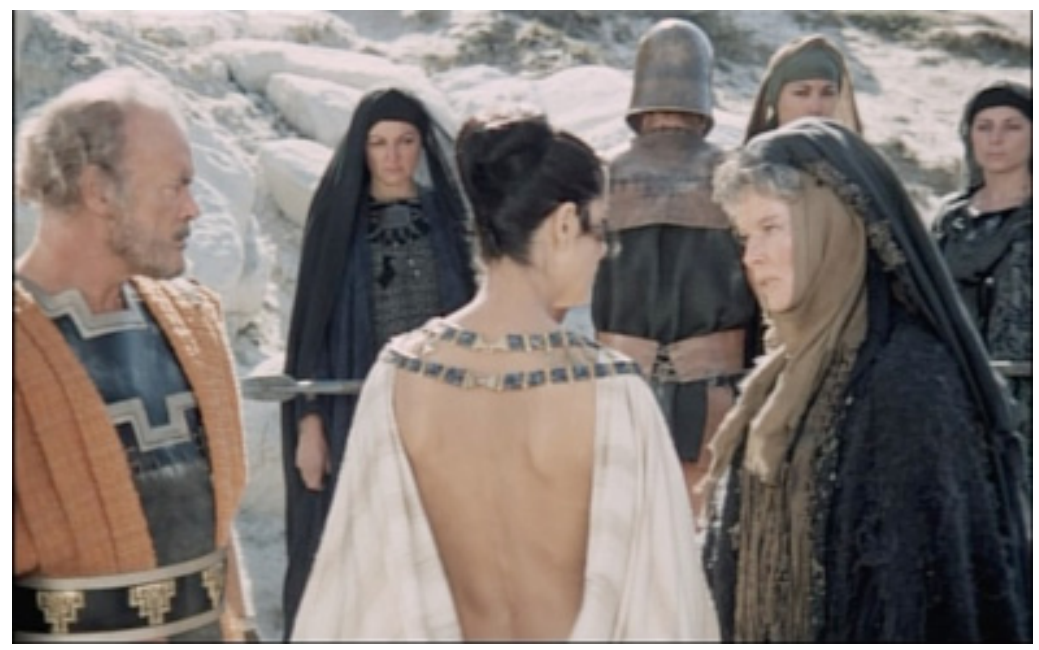

FIGURE 23: The Trojan Women. CACOYANNIS (1971)

Over three decades, from the mid-1960s to 2000, had to pass before the silver screen returned to classical antiquity - with a vengeance. The unexpected global success of Ridley Scott's Gladiator revived a film genre long written off as outdated. But advanced computerized special effects, routinely used in science-fiction spectacles, could now show viewers the distant past in ways it had never been seen before. The year 2004 brought not one but two giant epics on classical Greek subjects, one from history (Oliver Stone's Alexander), the other from myth. The latter even had its own small-screen precursor. 


\subsection{Helen of Troy (2003)}

Presumably in anticipation of the big-screen release of Troy, John Kent Harrison directed this three-hour television film from a feminist script by Ronni Kern. Its heroine, played by former British model Sienna Guillory, starts out as a strong-willed tomboy. After Theseus kidnaps her-Harrison's is the only film to include this part of Helen's backstory - she begs him to end her virginity; surprisingly he demurs. Her foster father Tyndareus wants to get rid of Helen by marrying her off(FIG. 24). Aphrodite engineers her marriage to Menelaus. But Helen has already fallen in love with someone unknown, whom she has seen in a vision. Agamemnon has fallen in lust with Helen at first sight and contrives to have her displayed nude to the assembled Greek kings (FIG. 25). As in Wise's Helen of Troy, Paris arrives as a Trojan ambassador. He sees Helen naked; she recognizes the man from her vision. Helen saves Paris' life and, unlike Wise's Helen, impulsively leaves with him. When Troy falls, a helpless Menelaus must watch Helen being publicly raped by Agamemnon. Menelaus has devotedly loved her all these years and takes her back home. He knows that she does not and will not love him.

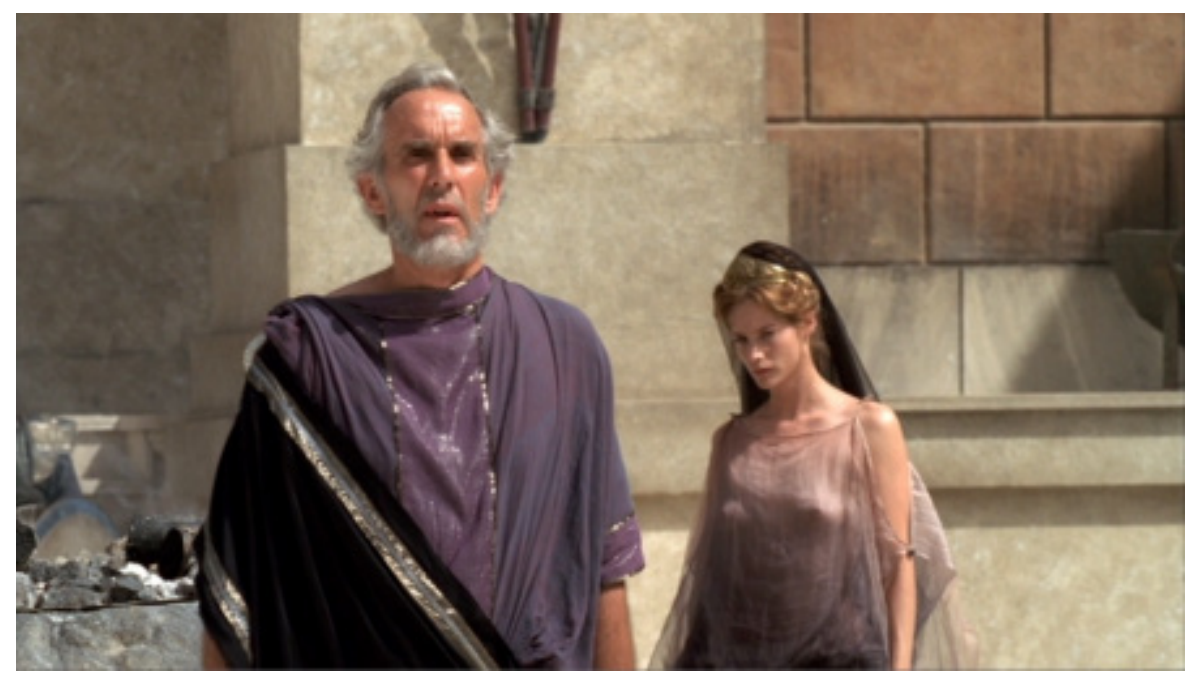

FIGURE 24: Helen of Troy. HARRISON (2003) 


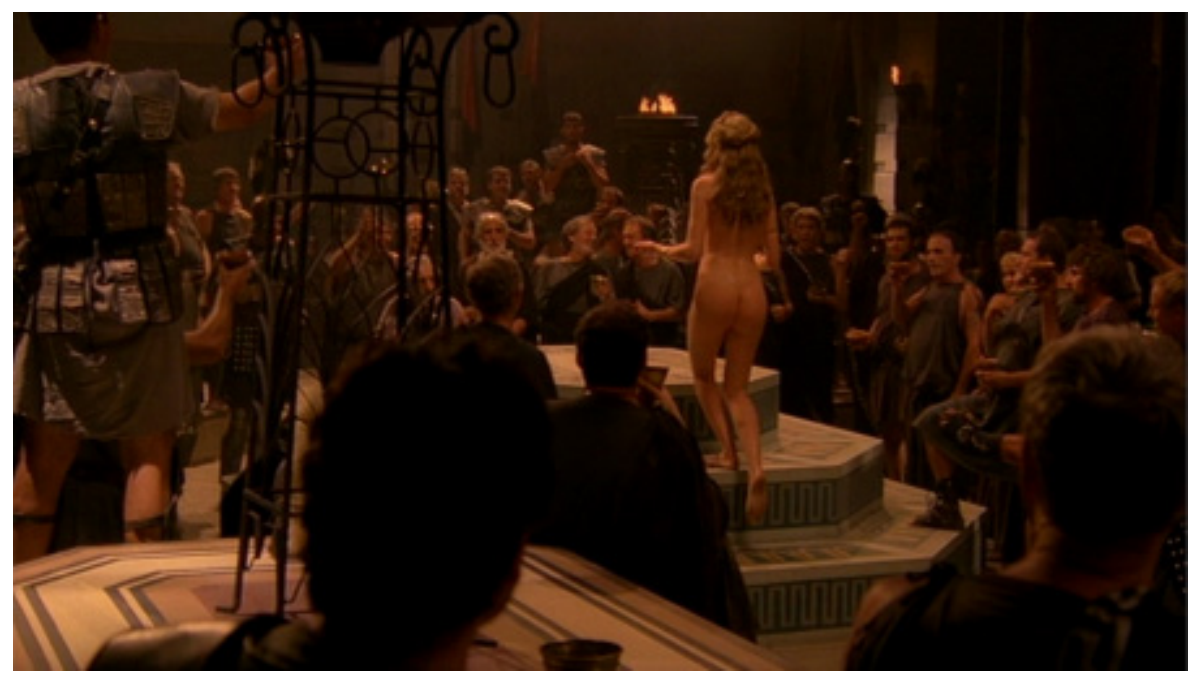

FIGURE 25: Helen of Troy. HARRISON (2003)

Guillory's Helen is not a stereotypical bland blond beauty but has more élan and vitality than most other actresses bring to the part. Her physical charms are repeatedly on view, perhaps to a degree unexpected in a film made for television. Connoisseurs and philosophers of posterior analytics will readily appreciate Helen's kallipygia. Her chest is usually covered by a loose and occasionally diaphanous garment, which serves to accentuate rather than to hide her well-rounded and freedom-loving personality. The message seems to be that, in a society whose patriarchal power structure is never seriously threatened, a spunky woman can preserve her spiritual and emotional independence even if she has to suffer public humiliation, kidnapping, and rape. Helen's Lib precedes Women's Lib. The shade of John Erskine might not have been terribly surprised.

\subsection{Troy (2004; Director's Cut, 2007)}

Director Wolfgang Petersen had read parts of Homer's Iliad in Greek in high school in Germany and had made waves with Das Boot (1981), his epic about doomed heroism set in World War II. So he was just right for this large-scale Homeric film. Troy was extensively criticized for changing ancient myth and the plot of the Iliad in unexpected ways, but this sort of thing is attested for ancient authors as well, to say nothing of filmmakers ever since Pastrone. In 2007 Petersen released a Director's 
Cut, which significantly improves on the original. ${ }^{13}$ There is a new opening scene and an expanded ending. The new version also contains more graphic violence and additional nudity.

As Helen, Petersen cast former German fashion model Diane Kruger, who is pretty, blond, and curvaceous enough for the part. Like Sienna Guillory, Kruger can be seen wearing gold jewelry on her head that appears patterned on pieces discovered by Heinrich Schliemann at the site of Hisarlik (FIG. 26). ${ }^{14}$ As was Wise's Helen, this one is married to a brutish Menelaus. Hector is leading a Trojan peace mission; his brother Paris, played by handsome and rather boyish Orlando Bloom, has other interests. Helen's elopement with Paris is presented as an escape from a Hades on earth and so becomes wholly forgivable. What Kruger once said about Helen may be worth keeping in mind:

What I really tried to do with Helen was make her show this sad side of her. She was married off at sixteen, was so young and living in this castle that she can't leave because of how she looks, and married to a man she hates and three times her age. Her beauty didn't do her any good, and she couldn't use it in any positive way or manipulative way.

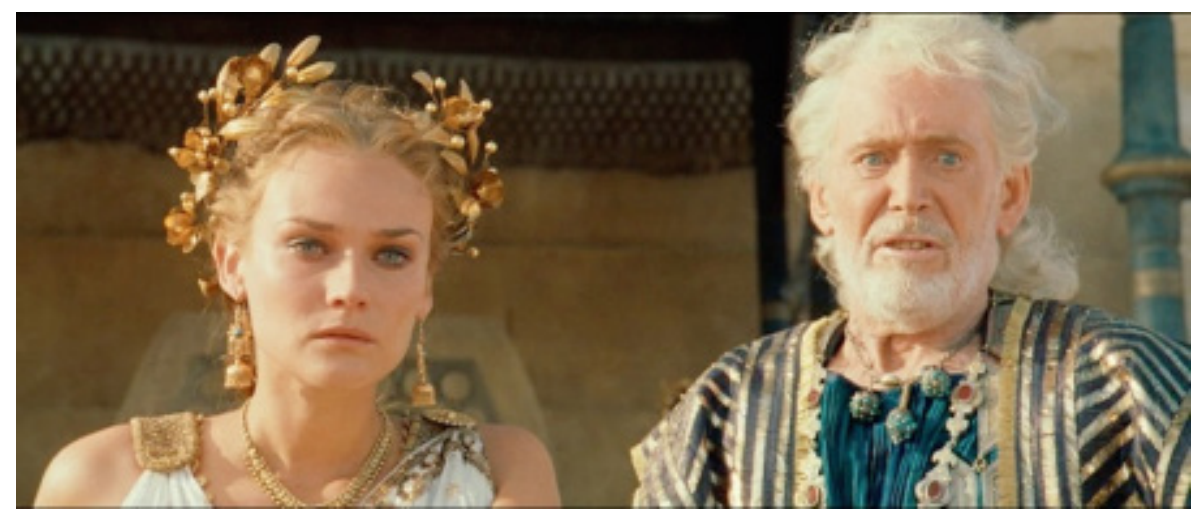

FIGURE 26: Troy. PETERSEN (2004)

\footnotetext{
${ }^{13}$ On the film see Winkler (2006 and 2015).

${ }^{14}$ That Helen's natural beauty was enhanced by attractive clothing and jewelry is frequently attested in ancient sources. A particular poignant example in its context is Virgil, Aeneid, 1.648-652 (Helen's cloak). For images, many in color, of the objects discovered by Schliemann see Tolstikov and Treister (1996).
} 
Paris survives the Trojan War and leaves the burning city of Troy with his sweetheart. Menelaus and Agamemnon are by now dead.

Petersen's epic does not give Helen as much screen time as she had had in Wise's and Harrison's versions. Her affair with Paris is juxtaposed to that of Achilles with Briseis - Achilles finds new meaning for his largely empty existence as a fighting machine, despite his greed for heroic glory - and to the perfect marital love between Hector and Andromache. Helen and Paris' affair is an enduring romance, but with more than a little sex in it. A comparison of the first scene between the lovers in Helen's bedroom in Sparta as presented in the two versions is instructive. While Kruger gets to show off her kallipygia in both, Petersen reveals more of her frontal physique in the Director's Cut (FIG. 27) than in the original release. By contrast, another intimate but non-sexual scene of the original version is missing from the Director's Cut. After Hector has killed Menelaus to save a cowardly Paris, Helen tends his wounds and his ego, saying: "Menelaus... lived for fighting. And every day I was with him, I wanted to walk into the sea and drown [...] I don't want a hero, my love. I want a man I can grow old with.” This excision was a wise choice on Petersen's part, for Helen's words had drawn large amounts of ridicule.

Petersen's Helen is not among the most memorable of portrayals. Still, Kruger manages to convey at least some of what she saw in Helen. A comparison with her 2012 performance as another doomed queen is telling. The Marie Antoinette she played in Benoît Jacquot's Farewell, My Queen (Les adieux à la reine) shows her considerably matured - to advantage.

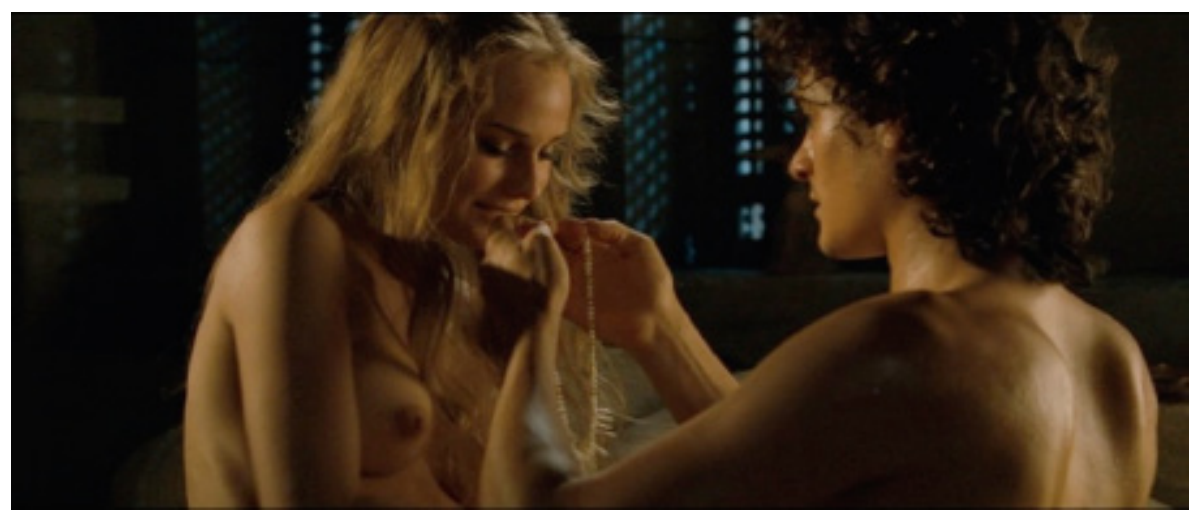

FIGURE 27: Troy. PETERSEN (Director's Cut, 2007) 
The visual appeal and commercial success of CGI-based epic films about ancient history and myth inevitably led to the production of films that were all spectacle and action but had little to offer in terms of compelling stories or characters whom viewers could care about. Perhaps our lastto-date film is a reaction to the overwhelming but empty special effects unleashed on the big screen: a long, good-looking, and character-driven retelling of the Odyssey on television, but with a twist. The two-season television series Rome $(2005,2007)$ may conceivably have inspired, if that is the right word, the production of this one.

\subsection{Odysseus (2013)}

This twelve-part French television series with a running time of about ten hours was created by Frédéric Azémar, its chief writer, and directed by Stéphane Giusti for broadcast over the prestigious FrenchGerman culture channel ARTE. It is what we could call a counterHomeric version of the Odyssey. Greek myth and literature have been changed into something completely different and with a lot more than just a little sex in it. (Warning to all traditionalists, Homer aficionados, and classical scholars: Watch this at your own risk!) The film's main character is Penelope, who has her hands full not only with the suitors but also with Telemachus and, worst of all, with Odysseus himself after his return. Viewers may be forgiven if they cannot decide whether this Odysseus is a war veteran suffering from Post-Traumatic Stress Disorder or simply a jerk, despite his originally passionate reunion with his faithful wife. ${ }^{15}$ There is also a blind youngster called Homer, who records for posterity what happens by dictating his verse to a scribe.

Petersen's Agamemnon had pursued ruthless imperialist dreams and come to a sticky end. This time it is Menelaus' turn. He intends to take military advantage of the power vacuum on Ithaca while Odysseus is absent. Menelaus visits Ithaca in the company of his wife. Helen is wearing a flowing white robe that also covers her head and keeps her face hidden. When she removes her veil we see a subdued Helen (FIG. 28). Helen says that, even if she had not gone with Paris, the Greeks would still have attacked Troy. This is a cliché found earlier in Wise's, Cacoyannis's, and Petersen's films. "I'd passionately loved Paris; I didn't

\footnotetext{
${ }^{15}$ Classical portrayals of Odysseus as villain, especially on the tragic stage, may come to mind here. On the subject see Stanford (1954), several rpts.
} 
know that this passion would lead to a bloodbath," Helen confides to a Trojan princess who is now Penelope's slave and whose daughter is Telemachus' lover. This Helen makes no more than a cameo appearance, but she contrasts with virtually all others ever put on screen. She is mostly surrounded by half-light and half-darkness, a symbolic chiaroscuro that is meant to tell us about her sad fate. Penelope discovers marks of physical abuse on Helen's body. Helen explains: "Every day Menelaus makes me pay for his degradation. He wants me to carry my crime on my body in order to be sure that I'll never forget it." Penelope chides her for causing immense suffering, but Helen pleads youthful innocence and adds that she did not want to call the gods' revenge upon herself." "Revenge of men," not of gods, Penelope retorts, "has punished you." "I am paying for all women," Helen says.

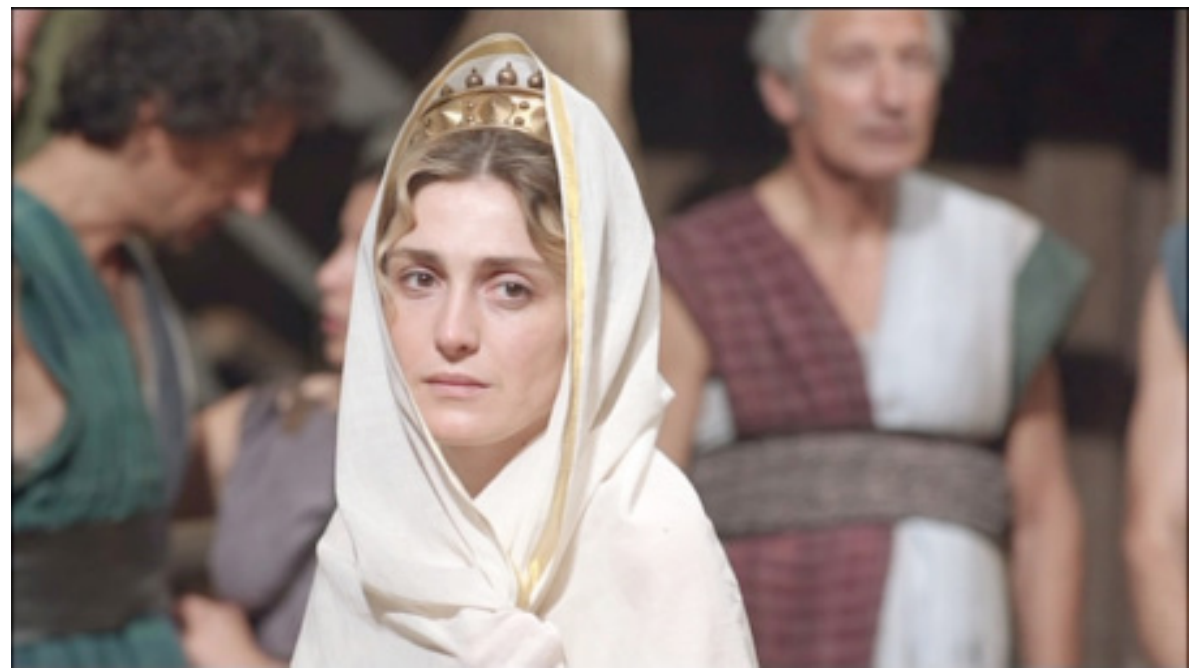

FIGURE 28: Odysseus. GIUSTI (2013)

The minor part of Helen in Odysseus might be negligible if it were not for actress Julie Gayet, who manages to infuse a certain tristesse into the few moments she has. But there is a kind of extratextual twist, if it may be called that. Tabloid headlines in 2014 revealed Gayet to be the mistress of French President François Hollande, who was at that time engaged in an affair with another woman. D'Hélène à Julie: plus ça change, plus c'est la même chose. 


\subsection{L'envoi: Hedy's Helen and the Eternal Woman}

We have now come to the end of our appreciation of Hellenic (and Helenic) beauty. Our short survey of Helen as damned damsel (for adultery and for causing a huge war) and blessed damozel (for her beauty), as seductive siren and femme fatale is, of course, woefully incomplete. Let us therefore pay a final tribute to the bevy of beauteous bodies by remembering just one other Helen. Austrian Hedy Lamarr had caused a scandal, and launched her international career, in 1933 with a brief nude scene in Ecstasy. Arrived in Hollywood, she was the titular seductress in Cecil B. DeMille's Samson and Delilah (1949). In 1954 she played Helen of Troy in the segment "The Face That Launched a Thousand Ships" in director Marc Allegret's ill-fated and now seldom seen Loves of Three Queens (L'amante di Paride). Massimo Serato was her Paris (FIGS. 2930). Lamarr also played Empress Josephine and Geneviève of Brabant. The film's original three-hour version, titled L'eterna femmina ("The Eternal Woman"), was never released. This title and that of Lamarr's final film (The Female Animal, 1958) tell us all we need to know about Hedy and Helen. Vive la beauté des femmes - au bonheur ou malheur des hommes! 


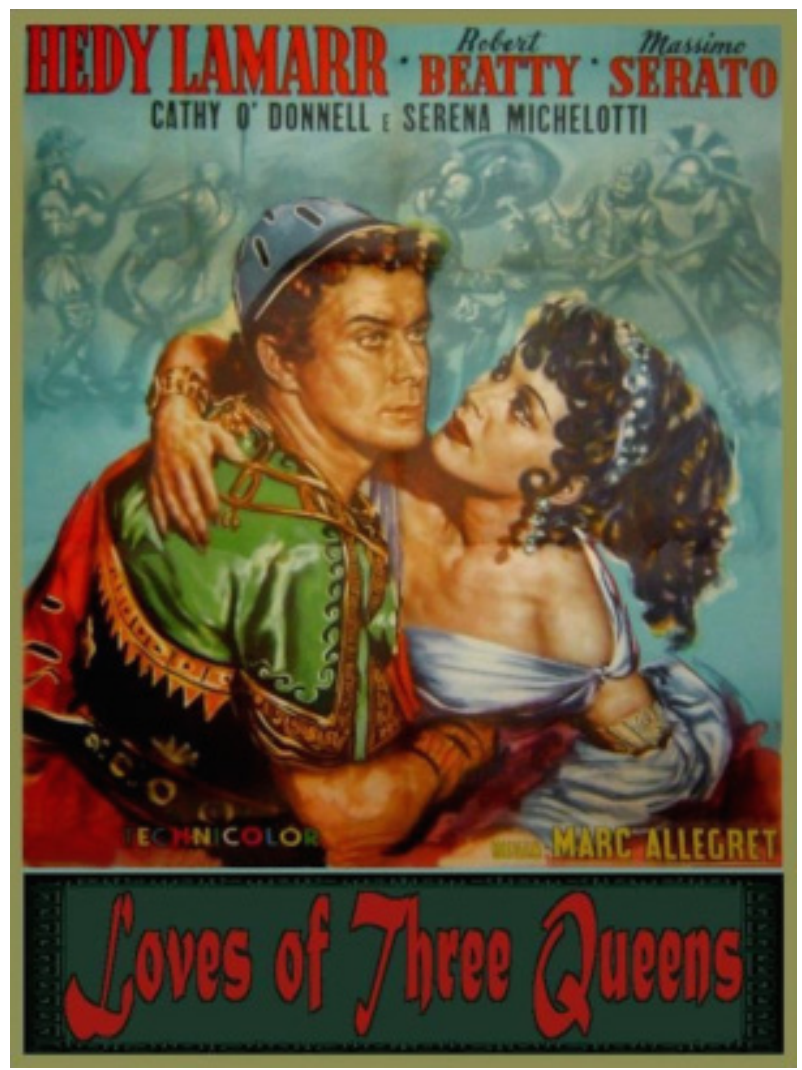

FIGURE 29: L'amante di Paride. ALLEGRET (1954) 


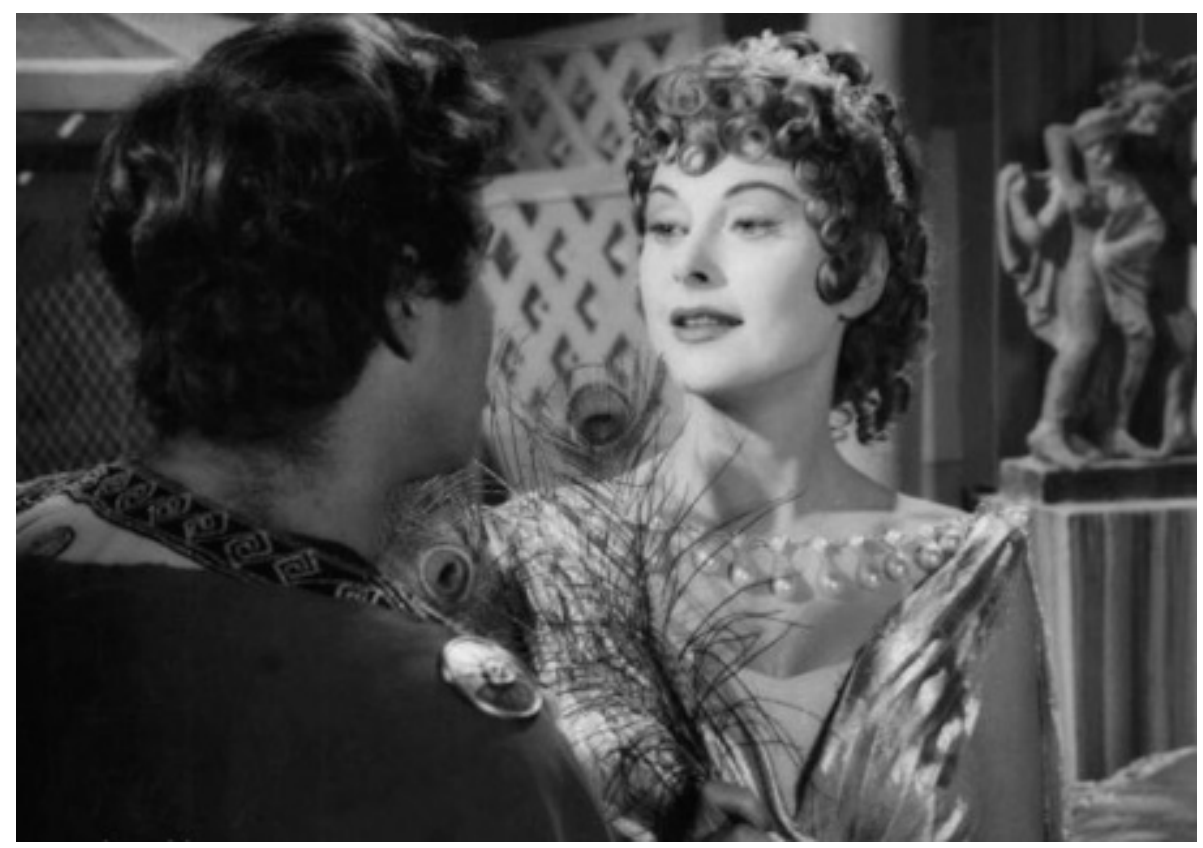

FIGURE 30: L'amante di Paride. ALLEGRET (1954)

\section{Fade-Out: Desire and Immortality}

"Sweet Helen, make me immortal with a kiss," Marlowe's Faustus continued immediately after posing his immortal question about her face. Robert Wise's screenwriters had King Priam quote part of this question upon first seeing Helen in Troy: "The face that launched a thousand ships," he muses. They also provided Paris with a nearly verbatim restatement of what Faustus said next: "Make me immortal with your kiss." The cinema is the best medium to do just that. As long as we watch films and remember their stories and characters, we preserve their immortality. Wise's writers knew this as well. They had Helen tell Paris: "What is remembered is forever young." This may sound like a saccharine cliché, but it is true nevertheless. Before THE END appears on screen, Wise's Helen remembers an exchange she had with Paris, killed by Menelaus during Troy's fall. We hear it in voice-over: 
HeLEN: What has been lived and shared is never lost.

PARIS: Never, Helen.

HeLEN: Then this is not good-bye. You shall always be with me.

PARIS: And you with me.

And we with her. THE END is not the end, for the cinema has launched, and doubtless will continue to launch, if not a thousand then a sufficiently large number of films to keep Helen's memory alive. Why the cinema more than any other modern medium? The end of the openingcredit sequence of Godard's Contempt provides an answer. Only a few seconds before the scene described above, Godard has his narrator quote a statement attributed to influential film scholar André Bazin: "The cinema,' said André Bazin, 'affords to our gaze an alternate world that conforms to our desires." So it does, and with a little sex in it. Herein lies its limitless appeal, not least when applied - retroactively, as it were - to stories and characters from myth or legend that have proven their fascination over millennia. Godard's narrator adds that Contempt will be the story of this alternate world. As mentioned, that story involves Homer and the Odyssey. And the Odyssey prominently features Helen in Book 4.

Who, we may ask, and not merely rhetorically, has been more appealing than Helen? A famous verdict about another ancient lover and seductress, albeit a historical and not a mythical one, applies here. This brief encomium comes from Marlowe's greatest rival. Here it is, but in a variation adapted to our topic:

Films cannot wither her, nor custom stale

her beauty's infinite variety on our screens.

\section{References}

BLONDELL, R. Helen of Troy: beauty, myth, devastation. Oxford: Oxford University Press, 2013.

COELHO, M.C.M.N. A vida privada de Helena de Tróia nos loucos anos 20 em Hollywood. Clássica, São Paulo, v. 26, n. 2, p. 191-223, 2013.

ERSKINE, J. The private life of Helen of Troy. Indianapolis: Bobbs Merrill, 1942. 
Fabian Sweater Girl Contest Scores a Hit. Showmen's Trade Review, v. 37 n. 8 , p. $20-21,1942$.

GLÜCKLICH, H-J. Die schöne Helena: Von Sparta über Troja nach Europa und Amerika. Göttingen: Vandenhoeck \& Ruprecht, 2000.

HOMEYER, H. Die spartanische Helena und der Trojanische Krieg: Wandlungen und Wanderungen eines Sagenkreises vom Altertum bis zur Gegenwart, Palingenesia 12, Wiesbaden: Steiner, 1977.

KONSTAN, D. Beauty: the fortunes of an ancient Greek idea. Oxford: Oxford University Press, 2014.

MARLOWE, C. The complete plays. F. Romany and R. Lindsey (Ed.). London: Penguin, 2003.

RODRIGUES, N. S. Helena de Troya en el séptimo arte. Ámbitos, Córdoba, 2nd series, v. 27, p. 27-37, 2012.

SHERER, M. R. The Legends of Troy in art and literature. New York: Phaidon Press for the Metropolitan Museum of Art, 1963.

SNELL, B. Was die Alten von der schönen Helena dachten. In: HÜPPAUF, B.R.; STERNBERGER, W. (Ed.). Über Literatur und Geschichte. Frankfurt am Main: Athenäum, 1973. p. 5-22.

STANFORD, W. B. The Ulysses theme: a study in the adaptability of a traditional hero. Oxford: Blackwell, 1954.

TOLSTIKOV, V.; TREISTER, M. The gold of Troy: searching for Homer's Fabled City. Tr. C. Sever and M. Bonnichsen. London: Thames \& Hudson, 1996.

WINKLER, M. M. (Ed.). Troy: from Homer's Iliad to Hollywood epic. Oxford: Blackwell, 2006.

WINKLER, M. M. Leaves of Homeric Storytelling: Wolfgang Petersen's Troy and Franco Rossi's Odissea / Foglie di narrazione omerica: Troy di Wolfgang Petersen e l'Odissea di Franco Rossi. In: CAVALLINI, E. (Ed.). Omero mediatico: Aspetti della ricezione omerica nella civiltà contemporanea. 2nd ed. Bologna: D.U. Press, 2010. p. 153-177.

WINKLER, M. M. Cinema and classical texts: Apollo's new light. Cambridge: Cambridge University Press, 2009; rpt. 2012. 
WINKLER, M. M. Three Queens: Helen, Penelope, and Dido in Franco Rossi's Odissea and Eneide. In: MORCILLO, M. G.; KNIPPSCHILD, S. (Ed.). Seduction and power: antiquity in the visual and performing arts. London: Bloomsbury Academic, 2013. p. 133-153.

WINKLER, M. M. (Ed.). Return to Troy: new essays on the Hollywood epic. Leiden: Brill, 2015. 